\title{
Mandatory Disclosure as a Solution to Agency Problems
}

\author{
Paul G. Mahoney $\dagger$
}

\section{INTRODUCTION}

Most sellers of goods or services are not legally compelled to provide particular information about their products to potential buyers; they must merely avoid making false claims. One important exception relates to securities. Firms that issue securities in the public markets must provide affirmative disclosures about the securities and the issuer. This is true not only in the United States, but in most developed countries. What accounts for the distinction between securities and other products?

Surprisingly few attempts have been made to justify the distinction on efficiency grounds. The initial approach of academic economists to the United States securities laws was to marshal empirical evidence that investors were, or were not, better off after the enactment of these laws. ${ }^{1}$ In response to the empirical debate, a small but influential theoretical literature has developed on the efficiency of mandatory disclosure. ${ }^{2}$ That literature identifies the goal of mandatory disclosure as helping market participants to determine prices for securities that accurately

$\dagger$ Assistant Professor of Law, University of Virginia School of Law. I thank Barry Adler, Mike Dooley, Jill Fisch, Reinier Kraakman, Ed Kitch, Julia Mahoney, Eric Orts, Steve Thel, George Triantis, Bill Williams, and workshop participants at the University of Pennsylvania Law School and the University of Toronto Faculty of Law for comments. Andrew Brownstein and Jennifer Mink provided excellent research assistance.

1 See George J. Stigler, Public Regulation of the Securities Markets, $37 \mathrm{~J}$ Bus 117 (1964) (arguing that returns to investors in new issues were unaffected by securities laws); Irwin Friend and Edward S. Herman, The S.E.C. Through a Glass Darkly, $37 \mathrm{~J}$ Bus 382 (1964) (challenging Stigler's analysis and countering that the variance of returns was lower post-1933); George J. Benston, Required Disclosure and the Stock Market: An Evaluation of the Securities Exchange Act of 1934, 63 Am Econ Rev 132 (Pt 1 1973) (evidence suggests that mandatory periodic disclosure does not benefit investors); Irwin Friend and Randolph Westerfield, Required Disclosure and the Stock Market: Comment, 65 Am Econ Rev 467 (Pt 1 1973) (challenging Benston's analysis).

2 The principal works are John C. Coffee, Jr., Market Failure and the Economic Case for a Mandatory Disclosure System, 70 Va L Rev 717 (1984); Frank H. Easterbrook and Daniel R. Fischel, Mandatory Disclosure and the Protection of Investors, $70 \mathrm{Va} \mathrm{L}$ Rev 669 (1984); and Gregg A. Jarrell, The Economic Effects of Federal Regulation of the Market for New Security Issues, 24 J L \& Econ 613 (1981). 
reflect all available information. ${ }^{3}$ Disclosure can contribute to informational efficiency (and ultimately to social welfare) by enabling traders to gather information, and thereby reflect new information in prices, at a reduced cost compared to a world without disclosure. This "accuracy enhancement" model has no competitors as an efficiency justification of disclosure. Critics of mandatory disclosure do not challenge the premise that the objective is to improve informational efficiency, but rather question whether the United States securities laws have achieved that objective. ${ }^{4}$

This Article presents an alternative efficiency justification for mandatory disclosure in securities markets. The alternative, which I call the "agency cost model," contends that the principal purpose of mandatory disclosure is to address certain agency problems that arise between corporate promoters and investors, and between corporate managers and shareholders. Disclosure can help reduce the cost of monitoring promoters' and managers' use of corporate assets for self-interested purposes. The modern literature on the firm recognizes the ubiquity and importance of such agency problems; ${ }^{5}$ moreover, rules mandating particular disclosures are common in principal-agent contexts. ${ }^{6}$ It therefore seems reasonable to consider the reduction of agency costs as an efficiency justification for mandatory disclosure in securities markets.

3 In addition to the sources cited in note 2, see Marcel Kahan, Securities Laws and the Social Costs of "Inaccurate” Stock Prices, 41 Duke L J 977, 979 (1992); Jeffrey N. Gordon and Lewis A. Kornhauser, Efficient Markets, Costly Information, and Securities Research, 60 NYU L Rev 761, 802 (1985); and Ronald J. Gilson and Reinier H. Kraakman, The Mechanisms of Market Efficiency, 70 Va L Rev 549, 601 (1984).

4 See, for example, Homer Kripke, The SEC and Corporate Disclosure: Regulation in Search of a Purpose (Law \& Business, 1979); Benston, $63 \mathrm{Am}$ Econ Rev at 133-34 (cited in note 1). Edmund Kitch challenges the notion that accuracy enhancement provides a coherent means of analyzing mandatory disclosure, but does not suggest an alternative model. See Edmund W. Kitch, The Theory and Practice of Securities Disclosure (working paper on file with U Chi L Rev).

5 See Michael C. Jensen, Agency Costs of Free Cash Flow, Corporate Finance and Takeovers, 76 Am Econ Rev 323 (Pt 2 1986); Frank H. Easterbrook, Two Agency-Cost Explanations of Dividends, 74 Am Econ Rev 650 (Pt 1 1984); Michael C. Jensen and William H. Meckling, Theory of the Firm: Managerial Behavior, Agency Costs and Ownership Structure, 3 J Fin Econ 305 (1976).

s See, for example, Moore \& Co. v T-A-L-L, Inc., 792 P2d 794, 798-99 (Colo 1990) (real estate broker's obligation to disclose offer to principal); Restatement (Second) of Agency $\$ 381$ (1958) ("Restatement of Agency") (agent's duty to give principal information relevant to affairs entrusted to agent); id $\S 382$ (duty to keep and render accounts). See also sources cited in note 11 (duty to disclose adverse interests). 
While reduction of agency costs may be a good reason to have mandatory disclosure, does it explain the mandatory disclosure system we have? If we look only at the statutes enacted by Congress in the 1930s, the agency cost explanation seems superior to the accuracy enhancement explanation. Mandatory disclosure was not a New Deal innovation, but evolved from the common law rules applicable to agents dealing adversely with their principals. These rules were adapted to securities markets as a means of dealing with a specific agency problem that I call the "promoter problem." The defining characteristic of the promoter problem was the use of the funds raised in connection with the creation and public flotation of a new company to purchase property or services from the company's promoter on terms that did not reflect arm's-length bargaining. The promoter problem led directly to the first mandatory disclosure statutes in England and was a significant part of the background of the United States securities laws, which borrowed heavily from the English statutes. The lists of disclosable items contained in the English and American statutes focused on the promoter problem and related agency problems. The history and initial design of these statutes, then, are consistent with the agency cost model.

The picture becomes more complicated when we focus on the present. The United States securities laws give the Securities and Exchange Commission ("SEC") the authority to alter the details of the disclosure system. ${ }^{7}$ It has done so in ways that diverge from the agency cost model and increasingly favor the accuracy enhancement model. The agency cost model is not, therefore, a convincing positive explanation for the present set of disclosure regulations contained in the SEC's rules and forms. Neither, however, is the accuracy enhancement model. The mandatory disclosure system as it now exists is the product of sixty years of shifting theoretical approaches and consequently does not reflect any one approach. I argue, however, that the shift toward accuracy enhancement has been normatively undesirable. Mandatory disclosure is most likely to be efficient when limited to the agency problems that spurred its creation.

The question whether mandatory disclosure serves, or should serve, primarily to resolve a set of agency problems or to improve informational efficiency is important because the two models have significantly different implications for disclosure policy. Acceptance of the accuracy enhancement model implies that

See text accompanying notes 172-73. 
information about the future is more important than information about the past, because information about the past is already reflected in prices. The disclosure system should therefore require managers of firms to discuss their beliefs about the future of the business, and should favor accounting statements that provide current values over those that reflect the historical cost of a company's assets. ${ }^{8}$ To the extent a company is widely followed by securities analysts, the need for each individual investor to obtain the historical data that the analysts have caused to be reflected in prices is reduced.

In recent years, the SEC has refined the mandatory disclosure system in ways that are consistent with these normative prescriptions. It has, for example, taken tentative steps toward incorporating forward-looking statements into disclosure documents; influenced the development of accounting standards that require reporting or disclosure of the current values of certain assets; and permitted larger, more widely followed companies to use less restrictive procedures for registering securities. ${ }^{9}$ The desirability of these changes depends in part on the validity of the accuracy enhancement model.

The normative prescriptions of the agency cost model tend to point in the opposite direction of those derived from the accuracy enhancement model. The agency cost model justifies the traditional, backward-looking model of mandatory disclosure as a means of helping investors uncover breaches of contractual or fiduciary obligations. Management's projections or views about the future of the business are not likely to contain information relevant to such breaches, and so the decision whether to disclose can be safely left unregulated. Accounting statements will identify how the firm's money and assets are being used, allowing investors to spot breaches of management's duties to the shareholders. For that purpose, employing historical cost is appropriate. The agency cost model, unlike the accuracy enhancement model, argues for a mandatory disclosure system that is more focused and more limited than the present one.

Part I of this Article identifies the specific agency problems that can be effectively addressed by mandatory disclosure, partic-

8 See Kripke, The SEC and Corporate Disclosure at 96-114, 179-198 (cited in note 4); George J. Benston, The Effectiveness and Effects of the SEC's Accounting Disclosure Requirements, in Henry G. Manne, ed, Economic Policy and the Regulation of Corporate Securities 23, 27-30 (American Enterprise Institute, 1969).

9 See Part V. 
ularly the promoter problem. Part II demonstrates how the promoter problem led to the development of mandatory disclosure rules in England, first by judges and later by Parliament. Part III traces the related history in the United States. Part IV argues that to the extent the United States securities laws codified and refined preexisting judicial solutions to the promoter problem and related agency problems, they were probably efficient. To the extent they authorized the expansion of the disclosure system to pursue the accuracy enhancement goal, however, they were probably inefficient. Part V discusses the implications of the agency cost model for present-day disclosure policy on matters such as disclosure of projections, the use of current value accounting, shelf registration, and executive compensation disclosure.

\section{The Agency Cost Model: A Description AND SOME TAXONOMY}

A corporate firm is "a web of agency relationships." Disclosure of conflicting interests is a staple of agency law. ${ }^{\text {li }}$ Perhaps, then, mandatory disclosure serves to reduce agency losses that arise because of the conflicting interests of promoters, directors, and managers, on the one hand, and investors on the other.

It is clear that part of the purpose of mandatory disclosure is to address some standard agency problems. In the United States, the Securities Exchange Act of 1934 ("Exchange Act") ${ }^{12}$ requires that all publicly traded companies make periodic disclosures, including detailed information about management's compensation and significant transactions between managers and the company. ${ }^{13}$ The evident purpose of such disclosures is to help the shareholders monitor management's self-interested behavior. By reducing monitoring costs, disclosure reduces overall agency losses. ${ }^{14}$

${ }^{10}$ Frank H. Easterbrook and Daniel R. Fischel, Corporate Control Transactions, 91 Yale L J 698, 700 (1982).

11 See Construction Techniques, Inc. v Dominske, 928 F2d 632, 636 (4th Cir 1991) (employee's duty to disclose ownership interest in employer's major supplier); Restatement of Agency $\$ \S 389,391$ (cited in note 6) (duties of agent not to deal with principal as adverse party or act on behalf of adverse party, respectively, without disclosure to and consent of principal).

12 Securities Exchange Act of 1934, Pub L No 291, 48 Stat 881, codified at 15 USC \$§ 78a-78ll (1988 \& Supp 1993).

${ }_{13}$ See Securities Exchange Act of 1934 § 12(b)(1)(D)-(G), 15 USC $\S 78 l(b)(1)(D)-(G)$.

14 Jensen and Meckling define agency costs to be the sum of monitoring expenditures by the principal, bonding expenditures by the agent, and residual losses not prevented by either monitoring or bonding. See Jensen and Meckling, $3 \mathrm{~J}$ Fin Econ at 308 (cited in note 5). By reducing shareholders' monitoring expenses, therefore, disclosure reduces the total 
But the most extensive mandatory disclosures are required at the time a company sells a new issue of securities to the public. The Securities Act of 1933 ("Securities Act") companies issuing securities to the public file with the SEC a detailed registration statement and provide extensive information in the prospectus provided to investors. ${ }^{16}$ The traditional explanation for these disclosures is that they provide the investor with all the "material facts" necessary to judge the value of the offered securities. ${ }^{17}$ Lurking beneath the surface, however, is an agency problem to which many of the disclosures are directly relevant.

The agency problem is most substantial as well as most easily observed in the context of a newly formed company selling shares to the public for the first time-the situation with which early mandatory disclosure statutes were principally concerned. ${ }^{18}$ The "promoter" typically identifies the asset or business to be incorporated, creates the corporation, and chooses an initial board of directors. ${ }^{19}$ The company, acting through its directors, purchases the assets it will use in its business, paying either with its stock or with cash raised from investors solicited by or on behalf of the promoter.

The company's creation and public flotation generates many profit-making opportunities. The cash raised by the sale of stock may be used to purchase a new business and to enter into a variety of long-term contractual relationships. The corporation may expend funds to hire advisors and consultants, pay commissions, and purchase other goods and services. The investors who provide the cash expect the company's board of directors to make sure that these transactions take place on the most favorable terms available to the company. Unfortunately, the directors are

agency cost associated with the corporate form.

${ }_{15}$ Securities Act of 1933 , Pub L No 22, 48 Stat 74, codified at 15 USC $\$ \S 77 \mathrm{a}-77 \mathrm{z}$ (1988 \& Supp 1993).

16 Securities Act of $1933 \S \S 5,7,10,15$ USC $\S \S 77 e, 77 \mathrm{~g}, 77 \mathrm{j}$.

17 See Ernst \& Ernst v Hochfelder, 425 US 185, 195 (1976); Croy v Campbell, 624 F2d 709, 712 (5th Cir 1980).

18 See Part II.

19 There is no universally accepted definition of the term "promoter," but the term is generally understood to mean a person who takes the necessary steps to form a company and to undertake the preliminary negotiations by which the company identifies a business or asset that it will ultimately acquire. See generally L.C.B. Gower, Principles of Modern Company Law 296-97 (Sweet \& Maxwell, 5th ed 1992). Under Delaware law, the person who files the certificate of incorporation, which commences the corporation's legal existence, is called the "incorporator" and has the authority prior to selection of directors to manage the affairs of the corporation, to adopt by-laws, and to elect directors. See 8 Del Code Ann $\$ 107$ (1991). 
chosen by the promoter and may be insufficiently independent to champion the shareholders' interests over those of the promoter. The promoter may wish to channel the profit-making opportunities identified above to himself or to his family, friends, and business associates. Because the promoter can arrange for all of these transactions prior to the company's creation, and then can choose a board of directors to complete the transactions on behalf of the company, the incoming shareholders may discover that the institutional features designed to protect their interests do not function properly. ${ }^{20}$

The result is the "promoter problem"-that is, the promoter may be able to sell property and services to the company without any arm's-length bargaining or independent scrutiny. The problem is not merely that a better-informed party sells without disclosing what he knows about the sold items. Rather, it is that the directors may not be, as the investors have a right to expect, faithful agents of the investors. It does not seem a very great stretch to conclude that the promoter, who controls the activities of the directors and is the main beneficiary of their breach of duty, might bear some responsibility for this state of affairs.

Courts have responded to the promoter problem by declaring that, prior to the selection of a genuinely independent board of directors, a promoter occupies a fiduciary position with respect to the corporation..$^{21}$ But there are many varieties of fiduciary duties. The principal duty courts have imposed on the promoter is to disclose the nature and extent of his financial interest. ${ }^{22}$ As discussed in more detail below, there is reason to believe that promoters and investors would agree to such a solution if given the opportunity to bargain. ${ }^{23}$ Would-be investors who understand the promoter problem want to know how much of the funds being raised in the offering will go toward the payment of commissions, fees, and similar expenses; whether the persons to whom those amounts are being paid have any preexisting relationship with the promoter or directors that might call into question whether the terms reflect arm's-length bargaining; and,

${ }^{20}$ Contracts entered into by the promoter on behalf of a company prior to the company's creation bind the company if they are ratified by the directors following its creation. See Stringer v Electronics Supply Corp., 23 Del Chanc 79, 2 A2d 78, 79-80 (1938)

${ }^{21}$ See, for example, Public Investment Ltd. $v$ Bandeirante Corp., 740 F2d 1222, 1234 n 72 (DC Cir 1984); Smith v Bitter, 319 NW2d 196, 200 (Iowa 1982).

${ }^{22}$ See Part II.B.

${ }^{23}$ See Part IV.A. 
generally, what other financial interests the promoter, directors, or persons connected with them have in the offering. (For example, is the promoter the beneficial owner of any of the property being purchased with the issue proceeds?) I will use the term "agency information" as a catchall for information fitting into any of those categories. A mandatory disclosure system that focuses principally on agency information follows what I call the "agency cost model" of disclosure.

This definition of agency information is deliberately restrictive. It is limited to information about significant transactions between the corporation and a corporate promoter or manager. The agency problems of concern here do not encompass the full range of problems normally discussed in the literature on corporate governance (including the problem of insufficient effort by the agent). Rather, the focus is on a narrower set of agency problems involving agent misbehavior, with which the common law of agency has traditionally been concerned. My claim is that mandatory disclosure is a reasonably effective means of dealing with this limited subset of agency problems, and has been proven so in other contexts. Mandatory securities disclosure rules arose out of, and in their infancy closely tracked, the disclosure obligations traditionally owed by an agent when dealing adversely with his principal. Although other sorts of agency problems exist, they were not the source of mandatory disclosure rules, and I do not believe they can be effectively addressed through mandatory disclosure rules. If they could be so addressed, one could recast the accuracy enhancement model in agency cost terms by arguing that all information about a company's performance is relevant to the shareholders' attempts to monitor managers. For my purposes, however, "agency information" is a distinctive set of information about the agent's use of his delegated powers to sell his own property or services to the principal.

\section{ThE BACKGRound of Mandatory Disclosure IN ENGLAND}

This Part examines the extent to which disclosure rules are and have been concerned with agency information, as opposed to the much broader category of accuracy-enhancing information (which encompasses any information that would affect the stock price). My argument is that mandatory disclosure got its start as a means of forcing disclosure of agency information in order to control the promoter problem. A substantial body of English case law arising prior to the first comprehensive disclosure statute, enacted by Parliament in 1900, shows that the promoter problem 
was significant. It also appears clear from the legislative history that the promoter problem was foremost in the minds of the legislators who enacted the initial disclosure law. Parliament's solution to the problem largely replicated, and expanded to some extent, the preexisting judicial solutions.

\section{A. The Promoter Problem}

Companies that raised capital by sales of stock to the public in nineteenth-century England were mostly promotional ventures. ${ }^{24}$ In that era, English companies, like their counterparts in the United States, used high par value stocks, and the purchase price at issuance was usually equal to par. ${ }^{25}$ Today this use of high par value stocks seems puzzling, but in its original context it served a useful purpose.$^{26}$ The formation of a company and its initial offering of stock to the public normally went handin-hand. The entrepreneur, or promoter, would describe his idea to potential investors, orally or by a written prospectus, and seek subscriptions for stock. The potential investor signed a subscription agreement providing that if sufficient subscriptions were obtained, the investor would buy a certain quantity of stock. The pace of communication necessarily dictated that the process of seeking and obtaining subscriptions was more leisurely than that of a modern public offering. Under these conditions, a subscriber might be concerned that other, more favored subscribers were receiving stock at lower prices. High par value stocks alleviated this concern because each purchaser was required by statute to pay at least the par value of his shares. ${ }^{27} \mathrm{~A}$ purchaser who paid no more than par therefore knew he was getting as good a deal as any other purchaser.

24 James Jefferys notes existing publicly held companies raising new capital by sales of stock beginning in 1885 , although he concludes that existing companies began to be significant competitors for new capital beginning only in 1900. See James B. Jefferys, Business Organization in Great Britain: 1856-1914 147-49 (Arno, 1977).

${ }_{25}$ See J.B. Jefferys, The Denomination and Character of Shares, 1855-1885, 16 Econ Hist Rev 45, 45-51 (1946). As to American practice, see Bayless Manning and James J. Hanks, Jr., Legal Capital 28 (Foundation, 3d ed 1990).

${ }^{26}$ The following discussion draws on Manning and Hanks's history of high-par stocks. See Manning and Hanks, Legal Capital at 22-28.

27 The concept of limited liability entered the Companies Acts through the device of the "company limited by shares," or "limited" company, in which "the Liability of its Members [is] limited to the Amount unpaid on their Shares." Companies Act, 1862, 25 \& 26 Vict, ch 89, § 8. A member (shareholder) who had not paid his "contribution" (par value) in full was liable to creditors for the shortfall. Id $\S 38$. 
The price of this certainty, however, was that future stock issues were difficult. It would be unlikely that at the time of a subsequent issue, the market value of the outstanding stock would be exactly equal to the par value. In addition, shares were typically sold partly-paid; that is, only a portion of the par value was paid at the outset, typically 15 to 40 percent, and the subscriber was liable for the difference. ${ }^{28}$ Thus, the need for additional capital could be met for some time by calls against the unpaid portion of the existing shares, reducing the need to sell new shares. It was an operating assumption of promoters that a company would originate with a stated capital in excess of the immediate needs of the business, and future capital needs would be met by a combination of retained earnings, borrowing, and additional calls of the unpaid capital. ${ }^{29}$

The observation that most stock sales were made by promotional companies is important in understanding the structure of English disclosure regulation. New-issue disclosure was thought of principally in relation to promotional companies. A businessman providing evidence in 1895 to the Departmental Committee of the Board of Trade, also known as the Davey Committee, drew an explicit distinction between problems arising at the time of company formation and those present on an ongoing basis. The former, he argued, related principally to the protection of prospective shareholders, while the latter related principally to the protection of creditors. ${ }^{30}$ That belief appears to have influenced the way in which Parliament approached disclosure regulation.

Periodic public disclosure by corporations for the benefit of creditors was a settled feature of English company law from its beginning. The first general corporate law, enacted in $1844,{ }^{31}$ did not provide for limited liability. Accordingly, the company was required to file a biannual public statement noting transfers

${ }^{28}$ See P.L. Cottrell, Industrial Finance: 1830-1914 84-86 (Methuen, 1979) (analyzing data from 1856 to 1882 ).

${ }_{29}$ See, for example, Report of the Select Committee on Limited Liability Acts, 10 Brit Parl Papers 393, 436-37 (1867) ("1867 Report") (testimony of William Newmarch, Esq.). Newmarch argued in favor of permitting companies to reduce their stated capital if it turned out that the capital needs of the business could be met from retained earnings. $\mathrm{He}$ argued that the possibility of future capital calls had inhibited the development of a secondary market in the shares of some companies.

${ }^{30}$ See Report of the Departmental Committee Appointed by the Board of Trade to Inquire what Amendments are Necessary in the Acts Relating to Joint Stock Companies Incorporated with Limited Liability under the Companies Acts, 1862 to 1890, 88 Brit Parl Papers 151, 239 (1895) ("1895 Report") (memorandum of Samuel Ogden, J.P.).

${ }^{31}$ An Act for the Registration, Incorporation, and Regulation of Joint Stock Companies, 7 \& 8 Vict, ch 110 (1844). 
of its shares, so that creditors would know the names and addresses of current investors in the event of nonpayment. ${ }^{32}$ Even after the advent of limited liability, companies still issued partly paid shares (a practice thought essential to make the company creditworthy ${ }^{33}$ ), and corporate laws therefore still required an annual filing of shareholder names and addresses and the amount of their unpaid subscriptions. ${ }^{34}$ It was natural that Parliament saw periodic disclosure and new-issue disclosure as serving two entirely different purposes.

A common form of new-company promotion in the late nineteenth century involved the purchase of an existing business or asset from its owner. ${ }^{35}$ The new corporation was sometimes formed by the owner himself, but toward the end of the century the owner frequently used the services of a professional promoter. ${ }^{36}$ A trustee acting on behalf of the prospective company entered into a contract to purchase the business or asset contingent upon a sufficient amount of capital being raised from the public. ${ }^{37}$ This trustee was typically an associate of the promoter, and his interests were aligned with those of the promoter rather than those of the incoming investors. The promoter drafted and filed the memorandum and articles (the charter) of the company, which stated that one of the purposes of the company was to consummate the purchase of the business or asset. The promoter then selected an initial board of directors and printed up a prospectus, describing the business and soliciting subscriptions for stock. When sufficient subscriptions were obtained, the stock was issued and the transactions described in the prospectus and the memorandum and articles were completed.

Such promotions were ripe for the development of the promoter problem, which took two basic forms. Often the promoter's entrepreneurial talent lay in identifying businesses that might be more efficiently operated in corporate form, purchasing those

32 See id ch 110, \& XI.

33 See, for example, 1867 Report II 187 at 414 (cited in note 29) (evidence of the Honorable Edward C. Curzon); Jefferys, Business Organization in Great Britain at 171 (cited in note 24).

34 See Companies Act, 1862, 25 \& 26 Vict, ch 89, § 26.

35 See J.H. Clapham, 3 An Economic History of Modern Britain 360 (Cambridge, 2d ed 1963); Jefferys, Business Organization in Great Britain at 126 (cited in note 24).

${ }^{36}$ Jefferys, Business Organization in Great Britain at 294-314 (cited in note 24). See also Cottrell, Industrial Finance at 113-41 (cited in note 28) (description of one prominent promoter's conversions of iron, coal, and steel concerns to limited liability form).

37 For a description of the professional promoter's role, see Francis B. Palmer, Palmer's Company Law 225 (Stevens \& Sons, Ist ed 1898). 
businesses, and promptly reselling them to newly formed corporations at a profit. ${ }^{38}$ The promoter, then, was often also the vendor to the corporation of its principal assets. In order to hide the extent of his profit, the promoter sometimes arranged a series of sales to nominees at increasing prices, a practice known as "loading" the purchase price. ${ }^{39}$ The last such nominee was named as the owner of the business in the prospectus. The prospectus could then truthfully state that the (nominal) vendor had recently purchased the property for a sum only slightly less than the price being paid by the new company, when in fact the real party in interest had purchased at a much lower price. ${ }^{40}$

That the practice of "loading" the purchase price was widespread appears clear from both the evidence presented to Parliament and the case law. In 1900, one of the Law Lords described a fact pattern occurring "over and over again":

[The promoters] issue a prospectus representing that they had agreed to purchase the property for a sum largely in excess of the amount which they had, in fact, to pay.... Secretly, and therefore dishonestly, they put into their own pockets the difference between the real and the pretended price. After a brief career the company is ordered to be wound up. In the course of the liquidation the trick is discovered. ${ }^{41}$

A second common practice was to omit any mention in the prospectus that fees would be paid to a professional promoter. ${ }^{42}$ A vendor sometimes hired a financier to help with the formation

38 See id at 325 .

39 For a description of the practice, see 1895 Report II 27 at 161 (cited in note 30). For examples, see Erlanger v New Sombrero Phosphate Co., 3 App Cas 1218, 1218-23 (HL 1878); Whaley Bridge Calico Printing Co. $v$ Green, 5 QB Div 109, 109-10 (1879).

${ }^{40}$ The usefulness of the device to promoters is testified to by the fact that it still occurs, despite more than a century of judicial and legislative attempts to prevent it. See Azrielli $v$ Cohen Law Offices, 21 F3d 512 (2d Cir 1994). There, a defendant purchased an apartment building for $\$ 770,000$ and sold it to certain other defendants for $\$ 989,000$. The latter defendants then created a corporation and sold it the building "at cost." Plaintiffs, who purchased shares in the corporation, brought a securities fraud action, claiming that the intermediate transaction was a sham designed to hide the fact that the arm's-length sale price was $\$ 770,000$ rather than $\$ 989,000$.

${ }_{11}$ Gluckstein v Barnes, App Cas 240, 248 ( $\mathrm{HL}$ 1900) (Macnaghten opinion). In that case, the vendors/promoters stated that they had purchased the business in question for a certain sum, without noting that part of the purchase price had been paid in outstanding debt securities of the business that they had acquired for a nominal sum, making the effective purchase price considerably less.

${ }^{42}$ See, for example, Emma Silver Mining Co. $v$ Grant, 11 Chanc Div 918, 918-25 (1879) (promoter's fees not disclosed to investors). 
and flotation of a company, and this professional promoter typically received a fee for his services from the vendor. Omitting the amount of such fees from the prospectus was not insignificant; promotional fees sometimes amounted to as much as 50 percent of the supplied capital. ${ }^{43}$ In addition, there is anecdotal evidence that companies formed with low promotional fees survived at a much higher rate than those formed with high fees. ${ }^{44}$ In short, investors were right to be concerned with nondisclosure of promotional fees.

To some extent, English law facilitated this practice of hiding the professional promoter's interest. The courts had created confusion about whether a company had the power to expend money in connection with its own flotation. ${ }^{45}$ This helped create demand for professional promoters because the company itself was wary of offering an underwriting commission or discount. The promoter's contractual relations were with the vendor rather than the company. This facilitated deception because the prospectus could truthfully state that the company was paying no promotional fees; when challenged, the vendor and professional promoter argued that the promoter's commission was a private matter between them. ${ }^{46}$

Both commentary and case law leave little doubt that the practice of hiding promotional fees, like the practice of "loading"

43 Cottrell, Industrial Finance at 131 (cited in note 28).

4 See id at 115, 131, 137 (noting one prominent promoter's successful ventures and his low fees); Jefferys, Business Organization in Great Britain at 301-302, (cited in note 24) (noting high promoter expenses and instability of companies promoted by "credit associations"); Leslie Hannah, The Rise of the Corporate Economy 19 (Methuen, 2d ed 1983) (noting high rate of insolvency among new public companies and contemporary "strong suspicion" of a link to "crooked," speculating promoters); H.A. Shannon, The First Five Thousand Limited Companies and Their Duration, 7 Econ Hist 396, 411-13 (1932) (noting high "mortality" rate for public companies and linking it to the "misdoings" of promoters).

Although of course it may be coincidental, the secular trend of survival rates of new promotions was downward during the second half of the nineteenth century as intermediaries became increasingly a part of company formation. As to the increasing role of intermediaries, see Jefferys, Business Organization in Great Britain at 294-309 (cited in note 24). As to the decline in survival rates, see H.A. Shannon, The Limited Companies of 1866-1883, 4 Econ Hist Rev 290, 295 (1933).

45 See Palmer, Palmer's Company Law at 231 (cited in note 37). In 1896, the Court of Appeal concluded that if the memorandum and articles permitted payment of an underwriting commission, a reasonable commission could lawfully be paid. Metropolitan Coal Consumers' Ass'n v Scrimgeour, 2 QB 604 (Ct App 1895). The Companies Act 1900, put the matter to rest by expressly permitting payment of underwriting commissions or discounts when authorized by the articles or disclosed in the prospectus. $63 \& 64$ Vict, ch 48 , $\S 8$.

45 See, for example, Lydney \& Wigpool Iron Ore Co. $v$ Bird, 33 Chanc Div 85, 86-88 (Ct App 1886). 
the purchase price, was widespread. In 1877, a judge of the Court of Appeal complained that "[t]hese cases have been so often before the Court unfortunately of late years . . . ."47 A single promoter, Albert Grant, who styled himself "the prince of promoters, ${ }^{143}$ accounted for at least three reported cases during the $1870 \mathrm{~s}^{49}$ Each had similar facts. Grant agreed with the vendor to form the company and solicit subscriptions in return for cash fees and other remuneration approximating 20 to 30 percent of the capital raised. Grant's interest in the promotion was not stated in the prospectus.

\section{B. The Judicial Response}

Both of the practices described above were carefully designed to avoid clear-cut fraud. The statements made in the prospectus about the ownership of the business, or about the expenses to be paid by the company, were technically true. They were also, however, manifestly incomplete to the point of being seriously misleading. The courts thus might have dealt with these practices by simply concluding that they amounted to fraudulent concealment or "half-truths."50 Instead, however, the courts chose a doctrinal approach that responded to the essence of the problem: the selfinterested use of money entrusted to the promoter and his associates by investors. The courts perceived the underlying agency problem and dealt with it using familiar tools from the law of agency.

Specifically, they concluded that a promoter was a fiduciary of the corporation and therefore had a duty to disclose an interest adverse to that of the corporation. ${ }^{51}$ The solution made sense. The promoter had to disclose his adverse interest to his principal, the corporation. Thus, he had either to provide a genuinely independent board of directors and disclose his interest to it, or to dis-

47 Bagnall v Carlton, 6 Chanc Div 371, 398-99 (Ct App 1877) (James opinion).

43 See Jefferys, Business Organization in Great Britain at 304 (cited in note 24).

49 Bagnall, 6 Chanc Div 371; Twycross $v$ Grant, 2 Common Pleas Div 469 (Ct App 1877); Emma Silver Mining Co. $v$ Grant, 11 Chanc Div 918 (1879). See also Rubery v Grant, 13 L Rep-Eq 443, 443-45 (Vice Chanc 1872) (suit by vendor against Grant for specific performance of promotional contract; vendor alleged that Grant had taken a larger portion of the proceeds than permitted by the contract).

so For modern examples, see Mends $v$ Dykstra, 195 Mont 440, 637 P2d 502, 508 (1981) (real estate vendor's statements, "while not strictly untrue," were highly misleading); Lindberg Cadillac Co. v Aron, 371 SW2d 651, 653 (Mo App 1963) (automobile vendor concealed engine cracks by filling them in; court found "fraudulent concealment").

${ }^{51}$ Erlanger $v$ New Sombrero Phosphate Co., 3 App Cas 1218 (HL 1878). See, for example, id at 1229-30 (Penzance opinion); id at 1236 (Cairns opinion). 
close his interest to the prospective investors. ${ }^{52}$ The net result in either event was to make it impossible for the promoter to stand on both sides of the transaction; he had to bargain over the price of his property and services with either the independent directors or the prospective investors.

The more difficult issue for the courts involved the precise contours of the fiduciary duty. It was clear that the promoter had to disclose, but what did he have to disclose, and what was the appropriate remedy if he failed to do so? It was clear from an early date that if a promoter sold property to the corporation without disclosing his interest to the independent directors or shareholders, the company could seek rescission of the sale. ${ }^{53}$ If successful, the company recaptured the shareholders' money from the promoter and reconveyed the property to him. In that event, rescission wiped out both any gain the promoter had obtained and any loss the company had suffered.

The courts had more trouble, however, deciding what standards should govern if rescission of the purchase was no longer feasible at the time the promoter's interest was discovered. In that event, the company might seek disgorgement of the vendor/promoter's profit, a common remedy for breach of trust. The courts' willingness to force the promoter to disgorge, however, turned in part on when and how the promoter had acquired the property he later sold to the corporation. If the promoter had begun to form the company prior to or simultaneously with his purchase, a court would conclude that he had purchased as a constructive trustee for the corporation, and the corporation was therefore entitled to any profit the promoter had made. ${ }^{54}$ If the promoter made his purchase before he set in motion the creation of the company, however, he could argue that at the time of his purchase, he was not acting as agent for the company, but purchasing on his own behalf for eventual resale. While he could still be required to disclose his financial interest to the company once he had become a fiduciary, he was not a constructive trustee, and his failure to disclose should entitle the company only to recover any damages it could prove.

${ }^{52}$ See id at 1236 (Cairns opinion) (disclosure to independent directors); Salomon $v$ Salomon, App Cas 22, 33 (H丩 1897) (disclosure to shareholders as valid alternative to disclosure to directors).

${ }^{53}$ See Erlanger, 3 App Cas at 1218, 1229.

st See id at 1235 (Cairns opinion). 
The courts were sympathetic to this line of reasoning. In In re Cape Breton Co., the first case that squarely presented the issue, the Court of Appeal concluded that once rescission had become impossible, the shareholders could not bring an action to recover the promoter's profit. ${ }^{55}$ The House of Lords affirmed, and one opinion suggested that the company's only recourse would be to recover any damages that it could prove resulted from the nondisclosure. ${ }^{56}$ In subsequent cases, however, the Court of Appeal backed away from the seemingly broad holding of Cape Breton. In one case the court held that the defendants, who had agreed among themselves to form a corporation at the time they purchased a property, were liable to disgorge their profit in connection with the purchase and resale. ${ }^{57}$ In another case, a judge suggested that Cape Breton was limited to situations in which the company's shareholders declined to seek rescission when it was still possible, and later sought damages. ${ }^{58}$ Nevertheless, the precise location of the line separating a promoter who had to disgorge his profits from one who needed only to pay any damages the company could prove was ambiguous. Thus, although the formal rule was that the promoter had to disclose the extent of any profits arising from his agency, the applicability of that rule to a promoter who sold previously-acquired property was not clear.

Before Parliament occupied the field, then, courts had alleviated the promoter problem by requiring promoters to disclose adverse interests to an independent party, be it the directors or the investors. Neither the scope of the duty nor the remedy was completely settled. What the investors desired, by contrast, was firmly established. They wanted to know how much profit promoters were making. The subsequent history of securities regulation is largely a history of how the investors got their way.

${ }^{s 5}$ See In re Cape Breton Co., 29 Chanc Div 795, 803-06 (Ct App 1885) (Cotton opinion), aff'd as Cavendish Bentinck v Fenn, 12 App Cas 652 (HL 1887). See also Ladywell Mining Co. $v$ Brookes, 35 Chanc Div 400, 407-09 (Ct App 1887) (Cotton opinion) (following Cape Breton).

${ }^{66}$ Cavendish Bentinck, 12 App Cas at 661-62 (Herschell opinion).

${ }^{57}$ In re Olympia Ltd., 2 Chanc 153, 170-71 (Ct App 1898), aff'd as Gluckstein v Barnes, App Cas 240 (HL 1900).

${ }^{5 s}$ Lydney \& Wigpool Iron Ore Co. v Bird, 33 Chanc Div 85, 94 (Ct App 1886). 
C. The Legislative Response

The Companies Act 1900 ("1900 Act") ${ }^{59}$ was the first statute in Anglo-American law to impose comprehensive disclosure requirements on companies selling securities to the public. The 1900 Act was the culmination of nearly thirty-five years of debate over the proper scope of the promoter's duty of disclosure. Parliament had taken its first tentative step toward mandatory disclosure by enacting Section 38 of the Companies Act, $1867 . .^{60} \mathrm{Sec}-$ tion 38 provided that a prospectus must disclose the parties to and dates of "any contract entered into by the company, or the promoters, directors, or trustees thereof, before the issue of such prospectus ...." The statute gave a direct right of action to shareholders, notwithstanding their lack of privity with the promoter and directors. Failure to make the required disclosures was deemed fraudulent "as regards any person taking shares in the company on the faith of such prospectus . . ."

Section 38 was most directly a response to the failure of the Overend Gurney bank, which had touched off the Panic of 1866. ${ }^{63}$ Not long before it collapsed, Overend Gurney had been converted from a partnership to a corporation. ${ }^{64}$ Its prospectus failed to disclose a separate agreement between the partnership and the corporation under which the partners retained and managed a pool of questionable loans. The partners guaranteed to the corporation payment when due of the balance of the loans. The loans went bad, and the partners had insufficient assets to satisfy the guarantee. Shareholders argued that had they been told of the arrangement, they would have realized that the bank had a poor loan portfolio and would not have invested.

One might accordingly view Section 38 as a first step toward requiring detailed disclosures about the business itself, as opposed to the underlying agency problems. Agency issues, however, were not absent from the Overend Gurney situation: the di-

59 63 \& 64 Vict, $\operatorname{ch} 48$.

6) 30 \& 31 Vict, ch 131, § 38 .

61 Id (capitalization modernized).

c2 Id (capitalization modernized).

* See Bishop Carleton Hunt, The Development of the Business Corporation in England, 1800-1867 153-156 (Harvard, 1936); Cottrell, Industrial Finance at 62 (cited in note 28).

at The facts are taken from the subsequent litigation, In re Overend, Gurney \& Co., 3 L Rep-Eq 576, 577-90 (Vice Chanc 1867), aff'd as Oakes $v$ Turquand \& Harding, 2 Eng \& Irish App 325 (1867). See also Overend, Gurney, \& Co. v Gurney, 4 Chanc App 701, 702-07 (1869), aff'd as Overend \& Gurney Co. $v$ Gibb, 5 Eng \& Irish App 480 (1872). 
rectors who failed to make adequate disclosure of the side agreement were also members of the former partnership, suggesting that the terms of the side agreement did not reflect arm's-length bargaining. Alternatively, then, Section 38 might be considered an attempt to deal with the promoter problem by giving investors a direct right of action against promoters and directors.

Section 38 had an unimpressive life, principally because the courts were unsure what it meant. Some courts initially reacted to this uncertainty by giving the statute a reading so narrow as to make it almost wholly ineffective. Those courts concluded that Section 38 applied only to contracts binding on the company itself, thus making it inapplicable to contracts between vendors and promoters. ${ }^{65}$ Eventually, however, the courts came to view Section 38 as another weapon for attacking the promoter problem. In 1880, the Court of Appeal conclusively determined that the statute covered contracts between a vendor and promoter. ${ }^{66}$ Of the eight cases construing Section 38 that appear in the Law Reports, six involve nondisclosure of a promoter's financial interest. ${ }^{67}$ The other two involve nondisclosure of a director's financial interest. ${ }^{68}$

When Parliament considered amending the Companies Act in the $1890 \mathrm{~s}$, it sought a more comprehensive solution to the promoter problem. With the 1900 Act, it mandated specific disclosures in new-issue prospectuses. The list of items to be disclosed, which appears in Section 10(1) of the 1900 Act, focused clearly on the promoter problem. The list included the names of the vendors of any property to be purchased with proceeds from the issue; ${ }^{69}$ all consideration paid for such property $;^{70}$ all consideration paid

65 See In re Coal Economising Gas Company (Gover's Case), 1 Chanc Div 182, 189 (Ct App 1875) (James opinion). See also Tuycross $v$ Grant, 2 Common Pleas Div 469, 497 (Ct App 1877) (Bramwell opinion).

${ }_{66}$ See Sullivan v Mitcalfe, 5 Common Pleas Div 455, 458-61 (Ct App 1880) (Thesiger opinion).

67 Aaron's Reefs, Ltd. $v$ Twiss, App Cas 273 (HL 1896); Greenwood v Leather Shod Wheel Co., [1900] 1 Chanc 421 (Ct App); Sullivan, 5 Common Pleas Div 455; Twycross, 2 Common Pleas Div 469; Gover's Case, 1 Chanc Div at 182; Craig $v$ Phillips, 3 Chanc Div 722 (1876). See also Capel \& Co. v Sim's Ships Composition Co., 58 L Times Rep 807 (Chanc 1888); Re The Ruby Consolidated Mining Co. (Askew's Case), 22 Weekly Rep 762 (Chanc 1874), rev'd, 9 Chanc App 664 (1874).

${ }^{68}$ Arkwright $v$ Newbold, 17 Chanc Div 301 (Ct App 1881); Cornell v Hay, 8 Common Pleas Div 328 (1873). See also Charlton v Hay, 31 L Times Rep 437 (QB Div 1874) (similar facts).

6 Companies Act 1900, 63 \& 64 Vict, ch 48, § 10(1)(f).

70 Id $\$ 10(1)(g)$. 
in connection with securing subscriptions for the stock; ${ }^{71}$ all other preliminary expenses; ${ }^{72}$ all consideration paid to promoters; ${ }^{73}$ and "full particulars" of every director's financial interest in either the promotion or any property to be acquired by the company. ${ }^{74}$ The requirement to disclose the identity of the vendors extended to all vendors-both direct and indirect-who would receive cash or securities in connection with the new issue. A promoter was therefore forced to disclose not only that he was financially interested, but also the amount of profit he stood to make if his purchase of any property to be resold to the corporation was contingent on the flotation or otherwise uncompleted at the time of flotation, if any part of his purchase price was to be paid with the issue proceeds, or if he was a director of the newlyformed company. ${ }^{75}$ The list also included a modified version of the prior Section 38, altered to clarify that the section's purpose was to combat the promoter problem. The new provision required disclosure of the dates and parties for every material contract entered into within three years prior to publication of the prospectus, but exempted contracts entered into in the ordinary course of business. ${ }^{76}$ The language of the statute thus leaves little doubt that Parliament's principal aim was to guard against the two forms of the promoter problem, as described above. ${ }^{77}$

71 Id $\$ 10(1)(h)$.

72 Id $\S 10(1)(i)$. The use of the phrase "preliminary expenses" to describe the expenses of the issue again suggests that Parliament thought that stock sales were made principally by promotional companies.

${ }_{73}$ Id $\$ 10(1)(j)$.

74 Id $\$ 10(1)(\mathrm{m})$.

75 This is how contemporary practitioners understood the working of the 1900 Act. See F. Gore-Browne and William Jordan, A Handy Book on the Formation, Management and Winding Up of Joint Stock Companies 97-99 (Jordan \& Sons, 23d ed 1900). The promoter's contract of purchase from the original owner, so long as made within three years of the date of the flotation, would also be covered by the requirement to disclose material contracts. Id at $98,101$.

${ }_{76}$ Companies Act 1900, $63 \& 64$ Vict, ch 48, $\& 10(1)(\mathrm{k})$. The requirement to disclose material contracts reaching back three years is not inconsistent with a concern for the promoter problem. Although the corporation typically was newly formed, the business being purchased by the new corporation had often been in operation for many years. The likely purpose of the three-year cutoff was to catch any sale of the business to anyone connected with the promoter over a reasonable period prior to the promotion.

7 See Cottrell, Industrial Finance at 74 (cited in note 28) ("It is clear from ... its contents that the main burden of the 1900 Act dealt with the problem of frauds on shareholders by promoters, especially those involving the loading of the purchase price.").

I put aside for later the question whether legislative involvement was necessary to assure these disclosures, or whether self-interest would have led promoters to disclose voluntarily. See Part IV.A. Based on the above history, disclosure of promoters' fees and profits, whether voluntary or mandatory, was inevitable. 
At the same time, the rhetoric of English policymakers and commentators of the $1890 \mathrm{~s}$, like that of their American counterparts in the 1930s, suggested a broader effort than simply refining the judicial solutions to the promoter problem. Disclosure was described as a means of improving investment decisions and preventing frauds. A statement to this effect from the report of the Davey Committee is cited in modern discussions of disclosure regulation:

It may be a counsel of perfection and impossible of attainment to say that a prospectus shall disclose everything which could reasonably influence the mind of an investor of average prudence. But this in the opinion of your Committee is the ideal to be aimed at, and for this purpose to secure the utmost publicity is the end to which new legislation on the formation of companies should be directed. ${ }^{78}$

The rhetoric, however, is misleading, for it deflects attention from what Parliament actually did, which was merely to depart incrementally from accepted equity principles. Where the courts had provided a remedy to a company that lacked actual or constructive knowledge of a promoter's interest, Parliament provided a list of precise disclosures relating to the interests of promoters and directors, and made the promoters and directors directly liable to investors for failing to make those disclosures. ${ }^{79}$ Tellingly, while Parliament largely followed the language of the Davey Committee's draft bill, it removed a clause in the draft requiring disclosure of "every material fact known to any director or promoter of the company who is a party to the issue of the prospectus." $" 10$

At the same time, the gap between rhetoric and reality may not be as wide as it appears at first glance. Our understanding of the language of the debate has been shaped by the subsequent history of the mandatory disclosure system. If we focus instead on the original context, which was the promoter problem, the links between such broad rhetoric and the narrower aim of the statute become clear. The disclosure of professional promoters' fees was less of a problem by 1900 , as judicial decisions had

781895 Report at $156, \S 6$, quoted in Louis Loss and Joel Seligman, 1 Securities Regulation 7 (Little, Brown, 1989).

79 Companies Act 1929, $19 \& 20$ Geo 5, ch 23, $\$ 37$ (imposing liability on directors and promoters for untrue statements contained in a prospectus).

${ }_{B O}$ The Davey Committee bill's disclosure requirements appear in the 1895 Report at 354-56 (cited in note 30 ). The referenced provision is in $\$ 14(1)(l)$. 
apparently induced a greater amount of disclosure. ${ }^{81}$ The real issue for debate in the late 1800 s was under what circumstances a vendor/promoter had to disclose the amount of his profit.

At the time, it would be quite natural for the pro-disclosure faction to use the phrase "all material information." After all, the standard rule applying to an agent who sells his own property to a principal with the principal's consent is to disclose "all facts which... would reasonably affect the principal's judgment" whether to buy the property. ${ }^{82}$ When courts chastised a promoter or other fiduciary for failing to disclose "material facts," it was because the fiduciary was making an undisclosed profit. The Economist, which was a strong supporter of disclosure regulation, used remarkably similar language in calling for disclosure of "all the information necessary to enable a reasonable investor to form a judgment" whether to invest. ${ }^{83}$ The context, however, was not one of helping the market determine an accurate price; it was one of informing investors about the conflicting interests of the promoter. Across the Atlantic, the United States Supreme Court had expressed the promoter's duty in a way that made the con-

81 The incidence of failing altogether to disclose promotional fees appears to account for fewer reported cases after about 1880 than in the two previous decades. The Economist, a persistent critic of promotional practices in the $1890 \mathrm{~s}$, admitted that the most notorious promoter of that era disclosed his financial interest to a greater extent than had other promoters. See Mr. Hooley's Bankruptcy, Economist 869 (June 11, 1898).

62 Restatement of Agency $\S 390$ (cited in note 6). See Dunne v English, 18 L Rep-Eq 524, 533 (1874):

It is not enough for an agent to tell the principal that he is going to have an interest in the purchase, or to have a part in the purchase. He must tell him all the material facts. He must make a full disclosure.

The facts of the Dunne case are ironic. English, like many promoters, purchased a property and promptly sold it to a corporation for more than double what he had paid. The corporation prospered, and so English faced no lawsuits based on his promotion. However, he had also acted as agent for the original vendor. He disclosed to the vendor that he was the purchaser, but failed to disclose that at the time of the purchase, he had already put into motion the creation of the company and the sale of the property to it at a huge profit. The vendor successfully sued to recover English's profit. The court made it clear that the "material fact" English failed to disclose was the profit he stood to gain on his purchase and sale. Id at 535-38.

${ }_{33}$ Company Law Reform, Economist 1619, 1619-20 (Nov 12, 1898). See also The Law of Limited Liability, Economist 662, 662 (May 26, 1888):

[A]ll that is required is, that an intending investor shall have at his disposal the facts upon which to form his judgment. For this purpose, it would be necessary that all contracts referring to the property to be acquired should be specified. At present, it is too often the custom simply to set out the contract between the immediate vendor and the company, and in this way it is possible to give either practically no information at all, or to convey an utterly false impression of the true facts of the case. 
text clear: "if persons start a company . . for the purpose of selling property to the company when organized, they must faithfully disclose all facts relating to the property which would influence" investors. ${ }^{84}$ In that context, the most material fact of all, and the one that occupied center stage in the debate, was the price the promoter had paid for the property.

\section{The BACKGRound OF MANDATORY Disclosure IN THE UNITED STATES}

At the time of their enactment, the United States securities laws represented a more substantial departure from prior legal norms than did the English disclosure statutes. Yet the first federal securities statute, and the only one concerned primarily with disclosure, draws heavily on the English precedents. Like the 1900 Act, the Securities Act is designed principally to deal with the promoter problem. The disclosure provisions of the Securities Act are therefore consistent with the agency cost model.

In making the claim that the disclosure regime provided by Congress targeted the promoter problem, I am not contending that the SEC exceeded its statutory authority by using mandatory disclosure for other purposes. Congress gave the SEC the authority to redesign the disclosure system as circumstances warranted, and Congress has not protested as the SEC has used that authority. Nevertheless, had the SEC not made such comprehensive use of its powers, the United States mandatory disclosure system would look quite similar to the English disclosure system on which it was modeled-that is, it would be focused principally on the promoter problem. In looking for an efficiency explanation for mandatory disclosure, we should not overlook the system that Congress borrowed from England in 1933.

\section{A. The Promoter Problem and the Judicial Response}

Reported cases in state courts prior to 1933 provide evidence that the promoter problem and judicial attempts to address it did not differ greatly between England and the United States. American vendor/promoters often sought to conceal their interest in property sold to the corporation. ${ }^{85}$ The fact patterns of many of

${ }^{84}$ Dickerman $v$ Northern Trust Co., 176 US 181, 204 (1899), quoting Victor Morawetz, 1 A Treatise on the Law of Private Corporations $\$ \S 291,294,546$ (Little, Brown, 2d ed 1886) (emphasis added).

${ }^{85}$ See, for example, Lomita Land \& Water Co. $v$ Robinson, $154 \mathrm{Cal} 36,97 \mathrm{P}$ 10, 11-13 
the unfaithful promoter cases of the late 19th and early 20th centuries are quite similar to those of unfaithful real estate broker cases of the same era. The latter often involved a real estate agent who sold the principal's property to a nominee, who in turn sold it to the agent. ${ }^{86}$ The concepts and terms the courts used to deal with cases involving unfaithful promoters and directors are nearly identical to those employed in cases involving unfaithful real estate brokers. ${ }^{87}$ State courts, like the English courts, fashioned a law to deal with the promoter problem, and many of the American cases cite the English precedents. ${ }^{88}$ Fixing the specific contours of the promoter's fiduciary duty posed similar doctrinal difficulties for courts on both sides of the Atlantic. The Supreme Court concluded in 1908 that the promoter's fiduciary obligation to disclose his interest in property sold to the corporation could be discharged by making the sale at a time when the promoter owned all of the outstanding stock. ${ }^{89}$ The promoter could immediately thereafter sell additional stock to the public without disclosing that he was the vendor to the corporation of the corporate assets. $^{90}$

(1908); Wills v Nehalem Coal Co., 52 Or 70, 96 P 528, 530 (1908); Yale Gas-Stove Co. $v$ Wilcox, 64 Conn 101, 29 A 303, 304 (1894).

${ }_{86}$ See, for example, Hogle $v$ Meyering, 161 Mich 472, 126 NW 1063, 1064 (1910); Easterly $v$ Mills, 54 Wash 356, 103 P 475, 476 (1909). Compare Humphrey $v$ Eddy Transportation Co., 107 Mich 163, $65 \mathrm{NW}$ 13, 13-14 (1895) (agent hired to sell two boats arranged sale to a nominee, who then resold them to a company partly owned by agent).

${ }_{87}$ Compare, for example, Tegarden v Big Star Zinc Co., 71 Ark 277, 72 SW 989, 991 (1903) (promoters may not "make a secret profit out of their purchases for the corporation"), with Hogle, $126 \mathrm{NW}$ at 1068 (real estate agent may not "make a secret profit out of the agency'); and Old Dominion Copper Mining \& Smelting Co. $v$ Bigelow, 188 Mass 315, $74 \mathrm{NE} \mathrm{653,658} \mathrm{(1905)} \mathrm{(promoter} \mathrm{is} \mathrm{"bound} \mathrm{to} \mathrm{disclose} \mathrm{all} \mathrm{facts} \mathrm{known} \mathrm{to} \mathrm{him} \mathrm{material} \mathrm{in}$ the sale" and may not conceal his interest by putting title in a "man of straw"), with Kingsley $v$ Wheeler, 95 Minn 360, $104 \mathrm{NW} 543,544$ (1905) (real estate agent "owes the duty of making a full, fair, and prompt disclosure of all facts" and may not conceal his interest by making intermediate sale to a "man of straw").

${ }^{88}$ The leading American case is Yale Gas-Stove Co., 29 A 303. See also Yeiser $v$ United States Board \& Paper Co., 107 F 340 (6th Cir 1901); Old Dominion Copper Mining \& Smelting Co. $v$ Bigelow, 203 Mass 159, 89 NE 193 (1909), aff'd, 225 US 111 (1912).

s9 Old Dominion Copper Mining \& Smelting Co. v Lewisohn, 210 US 206, 209, 212 (1908) (Holmes opinion).

so English judges similarly concluded that disclosure to all the initial shareholders was sufficient, at least when the plaintiff was a liquidator of the corporation or a purchaser of shares issued long after the company's formation. However, a number of them suggested that a person who purchased shares shortly after the company's formation could make a claim against the promoter. See In re British Seamless Paper Box Co., 17 Chanc Div 467, 477 (Ct App 1881) (James opinion); id at 478 (Brett opinion); In re Ambrose Lake Tin \& Copper Mining Co., 14 Chanc Div 390, 397 (Ct App 1880) (Brett opinion). 
As in England, the most difficult issue was whether the promoter had to disclose the extent of his profit, since the promoter's duty to disclose his adverse interest was clear at an early stage. American courts generally required the promoter to disclose the price he had paid for the property only if he had already become a promoter at the time he purchased, a question of fact in each case. ${ }^{11}$ The American courts also used the doctrine of "watered" stock as a tool to force disclosure of a promoter's profit. Corporate codes typically permitted the issuance of stock in return for property or services contributed to the corporation, but these had to be worth at least the par value of the stock received in return, a serious constraint.in an era of high-par stocks. ${ }^{92}$ If the promoter took stock with a par value in excess of the "value" of the property and services he provided, his stock was considered "watered." He was then liable to the company's creditors for the amount of the shortfall..$^{93}$

The watered stock issue had a direct connection to accounting principles. If the promoter and his associates owned all of the company's outstanding stock prior to the initial public offering, the company's balance sheet had to record the assets at the valuation the promoter had placed on them in order to bring the assets into balance with the capital account (the aggregate par value of the outstanding shares). An example may be useful. Assume a promoter purchases a factory for $\$ 10,000$ and subsequently forms a corporation with the objective of parting with 50 percent of his interest in the business. He takes 15,000 shares of stock in the company, with a par value of $\$ 1$ per share. Thus his opening balance sheet shows a capital of $\$ 15,000$. For the asset and liability sides to balance, he must record the value of the factory as $\$ 15,000$. He then sells 7,500 of his 15,000 shares to the public for $\$ 1$ per share, receiving $\$ 7,500$ for one-half of an asset that he had paid $\$ 10,000$ to purchase. In the event of a subsequent insolvency, creditors would attempt to make the promoter directly liable for part of the company's debts by challenging the $\$ 15,000$ valuation of the factory. There were a number of doctrines that in theory protected the promoter, such as a rule that the directors' valuation of property was conclusive absent

91 See Henderson v Plymouth Oil Co., 16 Del Chanc 347, 141 A 197, 203 (1928). See generally Manfred W. Ehrich, The Law of Promoters 219-26 (Bender, 1916).

92 See, for example, NY Stock Corp Law $\$ 69$ (Cahill 1930).

93 See, for example, Flint v Sebastian, 317 Mo 1344, 300 SW 798, 804 (Mo 1927); See $v$ Heppenheimer, $69 \mathrm{NJ} \mathrm{Eq} 36,61$ A 843, 849 (1905). 
fraud..$^{94}$ As a practical matter, however, a promoter in this position ran a risk that a court would find he had "watered" his stock if the value of the asset on the balance sheet was greater than the price he had paid..$^{95}$

The watered stock doctrine, therefore, constrained the promoter's ability to take a large profit on a sale of property to the corporation. That doctrine also had severe drawbacks. Most importantly, full disclosure of the promoter's profit did not protect the promoter from the company's creditors. Even if every investor understood and approved the promoter's receipt of stock with a par value of $\$ 15,000$ in return for property he had purchased for $\$ 10,000$, creditors could later challenge the transaction.

While an arm's-length deal between a promoter and investors would grant the promoter some financial reward for spotting the profit-making opportunity, the watered stock doctrine made these rewards risky. This can be seen most easily in the context of a common type of promotion of the nineteenth and early twentieth centuries-a mining venture. Assume a promoter possesses valuable and secret information that leads him to believe that a particular piece of farmland contains a mineral deposit worth $\$ 50,000$. He manages to purchase the property without revealing his information, paying $\$ 10,000$. Whether the promoter sells the property to an established mining company or forms his own mining company and "sells" the land to its shareholders, he will demand a price greater than $\$ 10,000$. The watered stock doctrine, however, made it risky for him to take his compensation in the form of stock. This was an even greater problem for promoters who contributed intangible property, such as patents or valuable information, because early-twentieth-century courts were extremely skeptical about the "value" of intangibles. ${ }^{96}$ The net result was that vendor/promoters were open to frequent ex post challenges for not having contributed property worth the par value of the stock they had received.

94 See, for example, NY Stock Corp Law $\S 69$.

gs See generally David L. Dodd, Stock Watering: The Judicial Valuation of Property for Stock-Issue Purposes 118-33 (Columbia, 1930).

${ }_{96}$ See, for example, Gillett $v$ Chicago Title \& Trust Co., $230 \mathrm{ml}$ 373, 82 NE 891, $904-$ 05 (1907) (rights to an unwritten play and several unpatented inventions deemed valueless by court, so that stock received for these intangibles "remained wholly unpaid"). See also Dodd, Stock Watering at 98 (cited in note 95) (noting that watered stock cases arise most frequently in connection with intangibles). 
Beginning in the 1910s, corporate codes began to permit nopar stock, and low-par stocks began to gain market acceptance. ${ }^{97}$ The watered stock doctrine therefore ceased to cause the practical difficulties outlined above. By the same token, however, the doctrine no longer forced the disclosure of promoters' financial interests.

The second paradigmatic promoter problem, the failure to disclose commissions, also existed in the United States, but in a slightly different form than in England. Rather than acting as professional promoters, receiving commissions from the vendors, the United States investment banks acted as underwriters, receiving discounts on the shares from the issuing companies. ${ }^{98}$ While the formal arrangements differed, the underlying function of soliciting investors did not.

Nondisclosure of underwriters' commissions lay at the very heart of the progressives' attack on Wall Street. In support of their arguments for a mandatory disclosure scheme, for example, President Roosevelt and congressional supporters of the Securities Act frequently quoted Louis Brandeis's 1914 book, Other People's Money. ${ }^{99}$ The book, however, was far from a "full disclosure" manifesto. Rather, it consisted mostly of an attack on concentrated wealth, particularly wealth controlled by investment bankers. ${ }^{100}$ Its assault on investment banks has much in common with the frequent attacks in late-nineteenth-century England on company promoters as a predatory and dishonest class. ${ }^{101}$ Brandeis's chapter on "What Publicity Can Do," the source of the New Dealers' references to "sunlight" as the best

97 See Manning and Hanks, Legal Capital at 28-30 (cited in note 25). J.B.R. Smith, New Jersey Corporation Law 25-30 (Soney \& Sage, 2d ed 1923), contains a discussion of the legislative history of the no-par provisions that emphasizes the role of the watered stock doctrine and its shortcomings in creating pressure for no-par stock.

9s See Vincent P. Carosso, Investment Banking in America: A History 53-54 (Harvard, 1970).

${ }_{99}$ Louis D. Brandeis, Other People's Money and How the Bankers Use It (Frederick A. Stokes, 1932). See Joel Seligman, The Transformation of Wall Street 41 (Houghton Mifflin, 1982) ("Rarely did Roosevelt speak about the stock market without invoking" Brandeis's book); 77 Cong Rec H 2933 (May 5, 1933) (statements of Rep. Marland, quoting Brandeis), reprinted in J.S. Ellenberger and Ellen P. Mahar, compilers, 1 legislative History of the Securities Act of 1933 and Securities Exchange Act of 1934 Item 7 at 2933 (Fred B. Rothman, 1973) ("Legislative History"); 77 Cong Rec H 2929 (May 5, 1933) (statement of Rep. Kelly, quoting Brandeis), reprinted in Ellenberger and Mahar, compilers, 1 Legislative History Item 7 at 2929.

${ }^{100}$ This point is also noted in Steve Thel, The Original Conception of Section 10(b) of the Securities Exchange Act, 42 Stan L Rev 385, 405-06 \& n 90 (1990).

101 See Jefferys, Business Organization in Great Britain at 308-309 (cited in note 24). 
remedy for the securities markets, does not call for comprehensive securities disclosure. Instead, it proposes only that underwriters' commissions be subject to mandatory disclosure. ${ }^{102}$

Roosevelt's own calls for "full disclosure" had a similar focus. The 1932 Democratic Party platform called for:

Protection of the investing public by requiring to be filed with the Government and carried in advertisements of all offerings of foreign and domestic stocks and bonds true information as to bonuses, commissions, principal invested and interests of sellers. ${ }^{103}$

The platform thus focused squarely on the two elements of the promoter problem identified by Parliament in 1900-vendors' and professional promoters' undisclosed financial interests. This statement falls far short of calling for disclosure of all "material facts." Similarly, in a campaign speech, Roosevelt proposed that "definite and accurate statements be made to the buyers in respect to the bonuses and commissions the sellers are to receive."104 The stage was thus set for Congress to borrow the English solution.

\section{B. The Legislative Response}

The new President and the 73d Congress identified a host of perceived abuses in the securities markets of the 1920s. In hearings that began in 1932 and ran until mid-1934, Congress examined and criticized a wide range of market practices, including short selling, leverage, insider trading, holding company structures, mergers, and securities activities of commercial banks. ${ }^{105}$ The first securities statute to emerge, however, was a new-issue disclosure statute that was similar to the disclosure provisions of England's 1900 Act, provisions which had been carried over with only minor changes into the Companies Act 1929 ("1929 Act"). ${ }^{106}$ Both the President and the Securities Act's principal

\footnotetext{
102 See Brandeis, Other People's Money at 92-108 (cited in note 99).

103 Samual I. Rosenman, compiler, 1 The Public Papers and Addresses of Franklin $D$. Roosevelt 667 (Random House, 1938) ("Roosevelt Papers").

${ }^{104}$ Id at 682 .

${ }_{105}$ The discussion in this paragraph and the next draws on Seligman, The Transformation of Wall Street at 1-100 (cited in note 99).

$1619 \& 20$ Geo 5, ch 23 (1929).
} 
draftsman, James Landis, identified the 1929 Act as the model for the Securities Act. ${ }^{107}$

Convenience undoubtedly explains in part why the Securities Act borrowed so heavily from the 1929 Act, notwithstanding the latter's narrow focus. The Roosevelt administration's broader goal, identified in the Democratic Party platform, was to bring the New York Stock Exchange under direct federal regulation. ${ }^{108}$ It was understood, however, that this task would be difficult: the Stock Exchange had made clear its absolute opposition to governmental oversight, and the Roosevelt administration was still undecided about what form of oversight it wanted. But after the President's early success in dealing with the bank crisis, he decided to introduce some securities legislation immediately, while public support was high, and to leave the more time-consuming stock exchange bill for later. ${ }^{109}$ The 1929 Act model provided a convenient means of satisfying Roosevelt's desire to have a law enacted immediately.

The use of the 1929 Act as a model was not purely a matter of convenience, however. As the above discussion of the 1932 election campaign indicates, Roosevelt had something along the lines of the English statute in mind for some time. A disclosure law based on the 1929 Act had additional attractions. Although it would be a significant extension of federal authority, substantively it would represent (as in England) only an incremental change from existing common law standards. Congress was also concerned that any attempt to address agency problems other than through disclosure might be unconstitutional. ${ }^{110}$ Basing the Securities Act on the 1929 Act also allowed supporters to point out that these disclosures had not harmed the English markets and were therefore not likely to harm the American markets. ${ }^{111}$ Finally, by making underwriters' and promoters' compensation the

107 See Franklin D. Roosevelt, 2 Complete Presidential Press Conferences of Franklin D. Roosevelt 347-48 (Da Capo, 1972); James M. Landis, The Legislative History of the Securities Act of 1933, 28 Geo Wash L Rev 29, 34 (1959).

10 See Rosenman, compiler, 1 Roosevelt Papers at 667 (cited in note 103).

109 See Thel, 42 Stan L Rev at 416 (cited in note 100).

110 See Jill E. Fisch, From Legitimacy to Logic: Reconstructing Proxy Regulation, 46 Vand L Rev 1129, 1181-82 (1993).

111 See Provide for the More Effective Supervision of Foreign Commercial Transactions, S Rep No 41, 73d Cong, 1st Sess 2 (1933), reprinted in Ellenberger and Mahar, compilers, 2 Legislative History Item 16 at 2 (cited in note 99) ("Long since, in England, the Government has endeavored to protect the purchasers of securities and it has succeeded by an act very similar to that here presented. The drastic provisions of the English securities law have not hampered honest investments ...."). 
focus of the "disclosure bill," the administration could be seen as attacking Wall Street rather than the business community generally.

The administration and Congress had an alternative model of new-issue regulation to consider. Virtually every state had a state securities, or "Blue Sky," law in 1933. Those laws required sellers of nonexempt securities to file disclosure documents with a state official prior to any offers or sales. ${ }^{112}$ Compared to the 1929 Act, the disclosure items specified in the Blue Sky laws tended to be less concerned with the promoter problem and more concerned with the prospects and value of the business itself. Typical disclosure items included a business plan, ${ }^{113}$ a schedule of the issuer's assets and an appraisal, ${ }^{114}$ abstracts of title to real estate owned by the issuer, ${ }^{115}$ a schedule of insurance carried, ${ }^{116}$ and even a statement of "all material facts ... relative to the character or value of such securities."117 These notions could not have been derived from the English precedents, for such disclosures were not a feature of English law. The distinctive features of the disclosures mandated by Blue Sky laws, however, reflected the distinctive purposes of those laws, purposes that were not shared by the federal statutes.

Most of the Blue Sky laws of that era provided for so-called "merit review," or a substantive review of the quality of the security. ${ }^{118}$ Although individual statutes varied widely, the typical one charged a state official with examining the information filed and any other information the official chose to require. The securities could be sold only with the official's permission, which was to be granted only if the official concluded that the business and the offering met specified standards: for example, the issuer's

112 For a detailed discussion of Blue Sky laws, see Louis Loss and Edward M. Cowett, Blue Sky Law (Little, Brown, 1958).

113 See, for example, Ark Stat \$ 8418k (1921 \& Supp 1927); Idaho Code Ann § 25-1602 (1932).

114 See, for example, Ill Rev Stat ch 32, III 262(6), 263 (Cahill 1933); Comp Stat Neb § 81-5405 (1930).

15 See United States Department of Commerce, A Study of the Economic and Legal Aspects of the Proposed Federal Securities Act, in Securities Act, Hearings on S 875 before the Senate Committee on Banking and Currency, 73d Cong, 1st Sess 312, 321 (1933) ("Senate Hearings"), reprinted in Ellenberger and Mahar, compilers, 2 Legislative History Item 21 at 312,321 (cited in note 99).

116 See id.

117 Va Code $\$ 3848(51)(f)$ (1930). See also Rev Stat Kan § 17-1228(6) (1923 \& Supp 1933) ("all knowledge or information ... relative to the character or value of such securities or of the property or earning power" of the issuer).

118 See Loss and Seligman, 1 Securities Regulation at 107-122 (cited in note 78). 
business was "sound," the terms of the offering were "fair," or the price of the securities would permit a "fair return." While these statutes were poorly drafted and economically naive, their purpose was clear-to curtail the sale of high-risk securities. ${ }^{120}$ Part of the underlying motivation for the Blue Sky laws, like the "watered stock" doctrine, was a deep suspicion of companies that had a significant amount of intangible assets. ${ }^{121}$

The more astute strategists within the Roosevelt administration recognized the crudeness of the Blue Sky approach. Early in the process of drafting the Securities Act, the administration considered and rejected merit review in favor of a pure disclosure statute, ${ }^{122}$ as did Sam Rayburn, the chairman of the House com-

119 See, for example, Idaho Code Ann $\S 25-1605$ (1932) (business and terms of sale must be "fair" and "promise a fair return on the stock"); Rev Stat Mo § 7730 (1929) (business may not be "based upon unsound business principles"). Some statutes also contained conditions that targeted the promoter problem. See, for example, Comp Stat Neb $\S 81-5408$ (1930) (no approval if the company is "a mere scheme of a promoter or promoters to obtain money or property at the expense of the purchasers" of the security); Va Code $§ 3848(58)$ (1930) (same).

${ }^{120}$ The statutes typically required full registration and merit review only for a residual class of securities, defined by removing various categories of blue-chip or investment-grade securities. See, for example, 111 Rev Stat ch 32, II 256 (Cahill 1933) (placing securities into four categories, the residual category, "Class $D$, , being described as those "based on prospective income").

Macey and Miller argue that the attempt to stop the sale of "speculative" securities was led by small banks and savings institutions that sought to suppress competition for depositors' funds from high-risk companies that could offer a high expected return. Jonathan R. Macey and Geoffrey P. Miller, Origin of the Blue Sky Laws, 70 Tex L Rev 347, 351, 365-67 (1991).

121 See, for example, Ala Code $§ 9886$ (1929) (securities commission must order an appraisal if a "material part" of the issuer's assets consists of intangibles); Ark Stat Ann § 8418m (1921 \& Supp 1927) (no more than 20 percent of capital may represent intangibles, and securities commission may require that any securities issued in return for intangibles be put in escrow); $\Pi 1$ Rev Stat ch 32, II 265 (any securities of Class D company issued in return for intangibles must be put in escrow; escrow agreement must provide that such securities will rank behind all other securities of corporation in event of bankruptcy or liquidation); Va Code $\$ 3848(49)$ (c) (1930) (including in list of securities subject to full registration those of issuers with a material amount of intangibles).

122 See Message from the President-Regulation of Security Issues, 77 Cong Rec S 937 (Mar 29, 1933), reprinted in Ellenberger and Mahar, compilers, 1 Legislative History Item 3 at 937 (cited in note 99):

Of course, the Federal Government cannot and should not take any action which might be construed as approving or guaranteeing that newly issued securities are sound in the sense that their value will be maintained or that the properties which they represent will earn profit.

There is, however, an obligation upon us to insist that every issue of new securities to be sold in interstate commerce shall be accompanied by full publicity and information, and that no essentially important element attending the issue shall be concealed from the buying public. 
mittee with jurisdiction over the securities bill. ${ }^{123}$ It seems entirely plausible to speculate that the President and Congress regarded substantial disclosures about an issuer's business and properties to be part and parcel of merit review, and thus inappropriate for a pure disclosure statute. This is all the more likely given the evidence that "full disclosure" was to Roosevelt a shorthand for disclosure of underwriters' commissions.

C. Does Agency or Accuracy Enhancement Better Explain the Statutes?

This Section looks in more detail at the design of the mandatory disclosure system in the Securities Act and the Exchange Act and argues that the design is more consistent with the agency approach than the accuracy enhancement approach. Congress's extensive borrowing from English law is an important piece of evidence in favor of the agency approach. However, Congress added a number of features to the mandatory disclosure system that were not a part of English law, and some of these appear to move in the direction of accuracy enhancement. I will argue, however, that these additional features can also be understood, and perhaps better understood, as responding to agency concerns. Thus, on balance the evidence supports the agency approach.

1. Statutory design as evidence of the agency approach.

The substantive provisions of the Securities Act retain the 1929 Act's focus on the promoter problem. Both statutes contain a schedule that lists the information to be disclosed. With a few exceptions, the items specified in Schedule A to the Securities Act $^{124}$ deal with the financial interests of promoters, underwriters, officers, directors, and controlling persons and with the use of the issue's proceeds. The House committee that drafted the bill

${ }^{123}$ The first bill introduced by Rayburn was an amalgamation of the 1929 Act and the Blue Sky laws, and provided for merit review. See Federal Securities Act, HR 4314, 73d Cong, 1st Sess (Mar 29, 1933), reprinted in Ellenberger and Mahar, compilers, 3 Legislative History at Item 22 (cited in note 99); Federal Securities Act, Hearing on HR 4314 before the House Committee on Interstate and Foreign Commerce, 73d Cong, 1st Sess 9 (1933) (statement of Huston Thompson, draftsman of HR 4314) ("House Hearings"), reprinted in Ellenberger and Mahar, compilers, 2 Legislative History Item 20 at 9, 11, 4445 (cited in note 99). Rayburn, after discussions with the Roosevelt administration, jettisoned that bill and accepted a substitute prepared by James Landis, Benjamin Cohen, and Thomas Corcoran. See Landis, 28 Geo Wash L Rev at 30-33 (cited in note 107).

12415 USC § 77aa, Schedule A (1988). 
referred to the disclosure provisions as "designed to reach items of distribution profits, watered values, and hidden interests that usually have not been revealed to the buyer despite their indispensable importance in appraising the soundness of a security." 125 Nearly one-half of the thirty-two items specified in Schedule A overlap in whole or in part with the nineteen items contained in the Fourth Schedule to the 1929 Act. ${ }^{126}$ It is equal$1 y$ instructive to note what is not included in Schedule A. There is a remarkable paucity of information about the issuer's business, other than its financial results. The only item that requires a description of the company's business is item (8), which calls simply for disclosure of "the general character of the business transacted or to be transacted."127 The contrast with modern disclosure standards could not be more stark. The SEC's current disclosure requirements call for a detailed description of the issuer's business, its properties, and any significant legal proceedings involving it; the description of what must be disclosed runs to six pages in the Code of Federal Regulations. ${ }^{128}$ The current disclosure system stands the statute on its head by making disclosures about the company's operations the cornerstone of the system. ${ }^{129}$

In general, the disclosure provisions of the Securities Act are not at all concerned with management's attempts to further the interests of shareholders. They do not require discussion of the company's day-to-day operations, its properties, its competitive or regulatory environment, or the views of its management about the company's financial performance. Any student of securities regulation is aware that such matters occupy a great deal of the SEC's attention. If one compares a modern prospectus, which is

125 Federal Supervision of Traffic in Investment Securities in Interstate Commerce, HR Rep No 85, 73d Cong, 1st Sess 7 (1933), reprinted in Ellenberger and Mahar, compilers, 2 Legislative History Item 18 at 7 (cited in note 99).

${ }_{126}$ Compare 15 USC § 77aa, Schedule A, with Companies Act 1929, 19 \& 20 Geo 5, ch 23, Fourth Schedule. In particular, items (20), (22), and (24) of Schedule A closely resemble, both in substance and wording, items 12, 15, and 13, respectively, of the Fourth Schedule. In addition, items (4), (9), (13) and (15)-(17), (14), (18), (19), and (21) of Schedule A are similar in greater or lesser degrees to items $4,16,5,3,11,10$, and 8 , respectively, of the Fourth Schedule.

127 USC \$ 77aa, Schedule A, item (8).

128 See 17 CFR § 229.101-.103 (1994).

129 See also Item 303, 17 CFR § 229.303 (1994), which calls for "[m]anagement's discussion and analysis of financial condition and results of operations," and Item 503(c), id $\S 229.503(\mathrm{c})$, which for certain issuers requires disclosure of "the principal factors that make the offering speculative or one of high risk." Schedule A contains nothing remotely comparable to either Item. 
jammed full of details on every aspect of the company's business, with Schedule A, the two barely seem related.

Congress understood that Schedule A did not cover every bit of information that an investor might want and an issuer might disclose. The Securities Act explicitly contemplates that the mandated information would constitute only part of a new-issue prospectus. ${ }^{130}$ Investors would of course expect, and issuers would provide, information about the business of the issuer as well. The statute permits, but does not require, the SEC to regulate that additional information. The statute does, however, provide remedies for materially false or misleading statements and includes a broad prohibition on fraud. ${ }^{131}$

Sophisticated contemporaries recognized that the Securities Act was functionally similar to the 1929 Act. There is little doubt that informed observers in 1933 regarded the Securities Act as a very conservative, incremental step. ${ }^{132}$ Felix Frankfurter referred to the Securities Act as a "belated and conservative attempt to curb the recurrence of old abuses." ${ }^{133}$ William Douglas belittled the Securities Act just after its passage as a "nineteethcentury piece of legislation" unresponsive to the great changes in industrial organization that in his view required more comprehensive governmental oversight of capital allocation. ${ }^{134}$ The legislation instead responded to a set of problems that existed well before the 1920s. It did so by substantially replicating an English solution that, in itself, drew heavily on accepted agency law.

The Exchange Act expanded the mandatory disclosure system to include ongoing, periodic disclosure by listed companies. ${ }^{135}$ Although Congress extended disclosure beyond the promotional stage, the principal consequence was to require ongoing

130 Section 10 of the Securities Act provides that a prospectus must contain the information contained in the registration statement, with certain exceptions, along with any additional information that the Commission (initially the Federal Trade Commission, later the SEC) requires. 15 USC $\$ 77 j(a)$, (c). The required information must be "placed in a conspicuous part of the prospectus and ... in type as large as that used generally in the body of the prospectus," id $\S 77 \mathrm{j}(\mathrm{e})$, thus showing that Congress contemplated that the required information would only be a portion of the prospectus. Indeed, the language seems to suggest that Congress assumed that the required information would be only a minor part of a prospectus.

131 Id $\$ \S 77 l(2), 77 \mathrm{q}$.

${ }^{132}$ See Seligman, The Transformation of Wall Street at 71-72 (cited in note 99), which cites the sources used here.

${ }^{133}$ Felix Frankfurter, The Federal Securities Act: II, Fortune 53 (Aug 1933).

134 William O. Douglas, Protecting the Investor, 23 Yale Rev 521, 529 (1934).

${ }_{13}$ The reporting requirement was extended to most publicly-held over-the-counter companies in 1964. See 15 USC $\S 78 l(g)$. 
disclosure of management's compensation and self-dealing transactions as well as financial information. The Exchange Act simply added a limited set of manager/shareholder agency problems to the promoter problem as appropriate subjects for mandatory disclosure. ${ }^{136}$ Section 12(b) of the Exchange Act ${ }^{137}$ provides a list of items to be disclosed. Like Schedule A, the twelve items set out in Section 12(b) include only a bare requirement for the "nature of the business,"138 but call for comprehensive information about officers, directors and principal shareholders and their compensation and dealings with the corporation. ${ }^{139}$ Section 12(b) thus retains Schedule A's resemblance to the English disclosure system. Interestingly, one of the most detailed provisions of Section 12(b) repeats Schedule A's requirement to disclose "material contracts," using language very similar to that of the 1900 Act, and reflecting the concerns about self-dealing that had influenced every disclosure statute since $1867 .{ }^{140}$

The Exchange Act was a more significant regulatory innovation than the Securities Act. It is not simply a disclosure statute, but imposes significant and far-reaching substantive regulation on the securities industry. However, it is interesting to note that other Exchange Act provisions also show Congress's concern for manager/shareholder agency problems. Section 14(a), ${ }^{141}$ which gives the SEC the authority to regulate proxy solicitation, was likely the result of congressional concern for management's misuse of the proxy machinery. ${ }^{142}$ Even Section $16,{ }^{143}$ which deals with trading in the company's equity securities by officers, directors, and controlling shareholders, may have been prompted by agency cost concerns. ${ }^{144}$ Section 16 regulates these transactions

\footnotetext{
${ }^{136}$ This was more controversial than the Securities Act's disclosure provisions because it impinged more closely on the states' authority over corporate governance.

13715 USC \& 781 .

${ }^{139}$ Exchange Act $\S 12(\mathrm{~b})(1)(\mathrm{A}), 15$ USC $\S 78 l(\mathrm{~b})(1)(\mathrm{A})$.

139 See id $\S 12(\mathrm{~b})(1)(\mathrm{D}), 15$ USC $\S 78 l(b)(1)(\mathrm{D})$ (executive compensation); id $\S$ 12(b)(1)(E), 15 USC \& 78l(b)(1)(E) (compensation to other highly-compensated employees); id $\S 12(\mathrm{~b})(1)(\mathrm{F}), 15$ USC § 78l(b)(1)(F) (bonus and profit-sharing plans); id § 12(b)(1)(G), 15 USC $\S 78 l(b)(1)(G)$ (management and service contracts).

${ }_{140}$ Id $\S 12(b)(1)(I), 15$ USC $\$ 78 l(b)(1)(I)$ (material contracts not in the ordinary course of business).

14115 USC \& 78n(a).

${ }_{142}$ See Fisch, 46 Vand L Rev at 1189 (cited in note 110).

${ }^{143} 15$ USC $\$ 78 p$.

14 See Steve Thel, The Genius of Section 16: Regulating the Management of Publicly Held Companies, 42 Hastings L J 393, 399 (1991) (a significant purpose of Section 16 was to "mov[e] the interest of those who control corporations into alignment with the interest of stockholders").
} 
partly by forcing insiders to disclose their trades.

2. Statutory design as evidence of the accuracy enhancement approach.

Notwithstanding the basic similarity between the Securities Act and the 1929 Act, and more particularly between the disclosure schedules, the Securities Act has a broader scope. It envisions a more intrusive form of regulation (the disclosures must be filed with, and may be reviewed by, the SEC prior to their use in a prospectus), and the disclosure schedule is more extensive. The Securities Act also gives the SEC the authority to prescribe additional or different disclosure items. Did Congress accordingly intend or foresee a disclosure system closer to the accuracy enhancement model than to the agency cost model?

The leading historian of the federal securities laws has argued that by virtue of the additional disclosure items, Schedule A more closely resembles the disclosure obligations contained in the New York Stock Exchange's listing standards than those contained in the 1929 Act. ${ }^{145}$ If so, then the Securities Act is not just targeted at the promoter problem. The disclosure requirements of the New York Stock Exchange in 1933 were concerned not only with agency problems, but also with the issuer's business and ongoing operations. The listing requirements, for example, called for information about the company's properties, its operations, and its financial position. ${ }^{146}$ The Stock Exchange was, within limits, pursuing a "full disclosure" ideal. ${ }^{147}$

One can take two different views of the relationship between Schedule A and the Stock Exchange's listing requirements. On the one hand, Congress included more in Schedule A than was in the 1929 Act, and the new items came largely from the Stock Exchange's listing requirements. One might conclude, therefore, that it was Congress's intent to bring the entire range of information relevant to pricing a security out of the realm of voluntary disclosure and into a mandatory system. On the other hand, one might note that Congress failed to include in Schedule A much of

\footnotetext{
${ }^{145}$ See Seligman, The Transformation of Wall Street at 46 (cited in note 99).

145 The pre-1933 New York Stock Exchange listing requirements are reprinted in J. Edward Meeker, The Work of the Stock Exchange 549-83 (Ronald Press, rev ed 1930).

147 Those disclosure requirements lend some credence to the argument that whatever benefits mandatory disclosure provides can be obtained through private arrangements without incurring the design problems that plague a government-run disclosure system. See Part IV.B.
} 
what is contained in the listing requirements. One could argue, therefore, that Congress did not understand Schedule $\mathrm{A}$ as a dramatic expansion of the 1929 Act's disclosure system.

The latter seems the stronger argument. What Congress took from the listing requirements falls basically into two categories. The first is information about the formal rights attaching to the security, and the relative position of the security vis-a-vis other equity and debt claims on the company. ${ }^{148}$ The second is an audited balance sheet and income statement. ${ }^{149}$ Both are consistent with the agency focus of the English statutes. In contrast, the elements of the listing requirements that Congress chose to omit are unambiguously related to company value. The omitted information includes descriptions and data concerning principal properties, output, employees, and franchises: in short, virtually all of the listing information related directly to the company's operations (other than its financial statements). Put in context, the dividing line between what is included in the Securities Act's mandatory system and what is not supports the agency cost explanation.

a) Information about capital structure. Schedule A, like the listing requirements, calls for detailed information about the characteristics of the security and its place in the issuer's capital structure. ${ }^{150}$ This information can be vital to understanding the financial interests of promoters. The rights and obligations of a security holder are defined by the express and implied contract between that holder, the issuer, and the other security holders. At the promotional stage, the other security holders likely include the promoter and/or associates of the promoter. Judging from reported cases, American promoters appear to have taken their profit less in the form of cash and more in the form of stock than their English counterparts. ${ }^{151}$ Incoming shareholders could not, therefore, have understood the financial interests of the promoter without understanding the rights and obligations attached to the outstanding securities.

148 See 15 USC § 77aa, Schedule A, items (9)-(12).

149 See id, items (25)-(26).

150 See note 148.

151 To the extent stock watering cases involved claims by other equity holders, as opposed to creditors, the claim typically was that the promoter had caused the company to issue stock to himself on terms more favorable than those offered the other shareholders. See Macey and Miller, 70 Tex L Rev at 355 (cited in note 120). 
The solution to that problem in the nineteenth century, both in England and America, was simple. Corporate stock was turned into a standardized commodity so that little specific disclosure about its attributes was needed. Capital structures typically contained only one class of stock and often contained no longterm debt at all. ${ }^{152}$ Stockholders typically purchased their stock at the promotional stage at a price equal to par. When subsequent sales of stock were made, the common law provided a preemptive right to the existing shareholders. ${ }^{153}$ As Berle and Means described it, nineteenth-century corporate law "authorized a specific capital structure, and the place of each shareholder in this capital structure was carefully defined."154 A share was thus very similar to an interest in a partnership, except by virtue of its transferability and limited liability.

By the end of the nineteenth century, this rigidity was breaking down in England as promoters tried new methods of extracting their profit from the flotation. An emerging practice was to create and issue to the vendors "founders' shares," or "managers' shares," having different rights than those attaching to the ordinary shares. ${ }^{155}$ The 1900 Act accordingly required disclosure of the number of such shares and the rights that attached to them. ${ }^{156}$ Thus, the Securities Act's requirement to disclose capital structure represents less of an innovation than it might appear.

In the United States by the 1930s, private ordering had replaced legislative mandate with respect to capital structure and the relative place of each investor. Corporate codes permitted nopar stock beginning in the 1910s. ${ }^{157}$ Some states permitted a corporate charter to remove preemptive rights. ${ }^{158}$ Greater powers were provided to alter terms of the charter and to create new classes of securities. ${ }^{159}$ The ability of an issuer to custom-tailor its capital structure increased substantially between 1900 and 1933, and investors consequently had an increased need to obtain

${ }^{152}$ See Jefferys, Business Organization in Great Britain at 216, 242-43 (cited in note 24) (little use of preferred stock or debt securities prior to $1880 \mathrm{~s}$ ).

${ }_{153}$ This was established in the United States by Gray v Portland Bank, 3 Mass 363, 383 (1807).

${ }^{15}$ Adolf A. Berle and Gardiner C. Means, The Modern Corporation and Private Property 148 (Macmillan, 1933).

${ }_{155}$ See Gore-Browne and Jordan, A Handy Book at 26-27 (cited in note 75).

$15563 \& 64$ Vict, ch 48, \$ 10(1)(a).

157 See Smith, New Jersey Corporation Law at 30 (cited in note 97).

15s See Berle and Means, The Modern Corporation at 144-46 (cited in note 154).

I59 Id at 148-52. 
specific information about the capital structure and their proposed place in it. The importance of that information to investors was so great that it inevitably had to become subject to either voluntary or mandatory disclosure, just like other information regarding vendors' and promoters' financial interests.

b) Financial statements. The Securities Act required that a registration statement contain an audited balance sheet and income statement. The same items were required on an ongoing basis under the Exchange Act. Although this requirement did not appear in the 1929 Act's disclosure schedule, on balance it seems consistent with the agency cost focus.

As to new-issue disclosure, Congress appears to have viewed the financial statement requirement as part of the solution to the promoter problem. The most persistent voice relating to accounting matters during the drafting and deliberation of the Securities Act was that of Robert Healey, Federal Trade Commission general counsel and later SEC Commissioner. ${ }^{160}$ Healey was a vigorous proponent of historical cost accounting and was highly critical of public utilities that had written up their assets to increase their rate base. ${ }^{161}$ Healey got his way. Language he proposed requiring that a registration statement contain a current balance sheet showing "the nature and cost" of the issuer's assets was included in the Securities Act. ${ }^{162}$

Write-ups on balance sheets were closely related to the phenomenon of stock watering, as described above. Stock watering was, in practical effect, an early attempt at current value accounting. Support for historical value accounting in the context of promotional companies was merely another means of trying to force disclosure of the price a promoter had paid for an asset.

160 See House Hearings, in Ellenberger and Mahar, compilers, 2 Legislative History Item 20 at 228-48 (cited in note 99) (statement of Robert E. Healey); Senate Hearings, in Ellenberger and Mahar, compilers, 2 Legislative History Item 21 at 211-26 (cited in note 99) (statement of Robert $\mathrm{E}$. Healey).

161 The reformers' goals with respect to public utilities should not be lumped together with those relating to ordinary industrial companies. Much of the regulatory concern with utilities was to minimize the rates charged to their public customers. Disclosure regulation with respect to utilities was intended in part to make the utilities' costs more transparent to their regulators as a means of tightening rate regulation. It was for that reason that candidate Roosevelt proposed more stringent securities disclosure requirements with respect to utilities than he had proposed generally. See Rosenman, compiler, 1 Roosevelt Papers at 737 (cited in note 103).

${ }_{162}$ See House Hearings, in 2 Legislative History Item 20 at 235 (cited in note 99) (statement of Robert E. Healey) (proposing language that became, with minor modifications, part of item (25) of Schedule A). 
It seems likely that Congress had watered stock in mind when it included the financial statement requirement in the Securities Act. ${ }^{163}$ The growing use of no-par and low-par stocks had made the watered stock doctrine less of a check on the promoter, and historical value accounting was a substitute that tended to force disclosure of the price a promoter had paid for property if it had been recently acquired. The ultimate effect of the financial statement requirement was not, therefore, much different from that of the other disclosure requirements. The balance sheet requirement forced a promoter who had recently purchased the property he contributed to disclose the cost of the property; the income statement requirement forced him to record commissions, fees, and similar expenses. At the same time, the Securities Act set the stage for the triumph of historical cost accounting as the basis for periodic disclosure. While the decision to embark on historical cost accounting has been much criticized, it makes perfect sense if the objective of financial reporting is not to help traders value firms, but merely to help shareholders uncover breaches of management's duties.

In the context of ongoing reporting, two distinct conceptions of the function of financial reporting are possible. One might view financial reporting as principally a form of monitoring for the benefit of shareholders, creditors, and other interested parties. Alternatively, one might view accounting as a means of providing a comprehensive picture of a firm's performance that may enable investors to form a better judgment of the value of the firm and its securities. While today we tend to emphasize the latter function, the former would have loomed much larger in the early part of the twentieth century.

The original purpose of accounting was to account-that is, to show how money and property entrusted to an agent had been used so that the principal could be assured that the agent had acted for the principal's benefit rather than the agent's. ${ }^{164}$ From an early stage in their development, business associations of all kinds were audited by representatives of the equity participants for the purpose of identifying and recovering unauthorized or self-interested expenditures by management. ${ }^{165}$ Such oversight

163 Seligman points to watered stock as an important part of the background for both state and federal securities laws in the period 1911 to 1934. See Joel Seligman, The Historical Need for a Mandatory Corporate Disclosure System, 9 J Corp L 1, 18-19 (1983).

104 See B.S. Yamey, Some Topics in the History of Financial Accounting in England, 1500-1900, in W.T. Baxter and Sidney Davidson, eds, Studies in Accounting 11, 11-12 (Institute of Chartered Accountants, 1977).

${ }_{165}$ See Ross L. Watts and Jerold L. Zimmerman, Agency Problems, Auditing and the 
by shareholders is a straightforward example of shareholder monitoring of management, as described in the modern literature on the theory of the firm. ${ }^{166}$ The need for a formal system of monitoring corporate expenditures increases as the number of shareholders increases and their involvement in the operation of the business decreases. It is therefore not surprising that an accountant would use the phrase "severance of ownership and control" in 1924 to describe the conundrum of the modern corporation, eight years before that concept entered the legal and economic literature with the publication of Berle and Means' The Modern Corporation and Private Property. ${ }^{167}$

Early audits were carried out by a committee of shareholders, and later statutes continued to give the shareholders the ultimate authority to name the auditors. ${ }^{168}$ That arrangement makes clear the importance of the monitoring function. Even as outside firms of professional auditors began to occupy the field in the late nineteenth century, however, the focus on agency issues continued. ${ }^{169}$ In America, the point was underscored by the fact that many of the early professional accountants were associated with English firms and audited American companies that sold securities in England. ${ }^{170}$ The distant investors obviously wanted someone whom they trusted to keep an eye on management's use of the corporate assets. An important feature of the outside accountant both then and now is "independence," which as an operational matter means that the auditors will report discovered breaches of management's duties to the shareholders. ${ }^{171}$

c) The SEC's plenary authority. The hardest piece of data to square with the agency cost explanation for the Securities

\footnotetext{
Theory of the Firm: Some Evidence, 26 J L \& Econ 613, 616-26 (1983).

166 Jensen and Meckling, $3 \mathrm{~J}$ Fin Econ 323 (cited in note 5).

167 Compare Henry Rand Hatfield, An Historical Defense of Bookkeeping, $37 \mathrm{~J}$ Acct 241, 251 (1924) ("In part the new significance of accounting is due to subdivision of ownership and the severance of ownership and control so characteristic of the corporate form of business organization."), with Berle and Means, The Modern Corporation at 4 (cited in note 154) (describing separation of ownership and control).

169 See Watts \& Zimmerman, $26 \mathrm{~J}$ L \& Econ at 624 (cited in note 165). See also 19 \& $20 \mathrm{Geo} 5, \mathrm{ch} 23, \S 132$ (1929) (providing for appointment of auditor at each annual general meeting).

169 See Watts and Zimmerman, $26 \mathrm{~J} \mathrm{~L} \mathrm{\&} \mathrm{Econ} \mathrm{at} \mathrm{628-33} \mathrm{(cited} \mathrm{in} \mathrm{note} \mathrm{165).}$

170 Id at 629-30. See also James Don Edwards, The Emergence of Public Accounting in the United States, 1748-1895, 29 Acct Rev 52 (1954). Edwards states that the principal function of late-nineteenth-century public accounting firms was to audit books "with the object mainly of discovering or preventing irregularities." Id at 63.

${ }_{171}$ Watts and Zimmerman, $26 \mathrm{~J} \mathrm{~L} \&$ Econ at 615 (cited in note 165).
} 
Act is Congress's decision to give a regulatory agency broad authority to expand or contract the disclosure system to the extent the agency thinks necessary. The statute gives the SEC the authority, when consistent with "the protection of investors," to require disclosures in addition to those required by Schedule $A$ and to permit issuers to omit information required by Schedule A. ${ }^{172}$ By providing this authority, it may be argued, Congress intentionally sowed the seeds of the accuracy enhancement approach.

Yet the anomaly may be less stark than it appears. Congress had already seen that the ability to create more complex capital structures necessitated more disclosures than originally required by Parliament in the 1900 Act. Similarly, there was no reason to think that the techniques of company promotion would remain static after 1933. It was natural, therefore, for a Congress that placed substantial faith in administrative expertise to give authority to an administrative agency to alter the disclosure system as changing times required. ${ }^{173}$ The relevant question, then, is not whether Congress gave the SEC the formal authority to expand the focus of the mandatory disclosure system, but whether that expansion was a wise use of the SEC's authority, a question $I$ address in the next Part.

d) Issuer strict liability. The Securities Act does not consist simply of the registration and disclosure requirements. It also contains liability provisions that make issuers, directors, underwriters, and accountants, among others, liable for misleading statements or omissions in registration statements and prospectuses. ${ }^{174}$ The issuer itself is strictly liable for material inaccuracies; other parties have affirmative defenses to the extent they can show that they met specified levels of care. ${ }^{175}$

Issuer strict liability seems anomalous if the statute, as I have argued, was primarily a response to the promoter problem. The purpose of issuer liability seems to be to increase the accuracy of information provided to the market, even at the cost of forcing one group of investors to make up the losses of another.

17215 USC $\S 77 \mathrm{~g}$. See also id $\S 77 \mathrm{j}(\mathrm{d})$ (SEC may prescribe contents of prospectuses).

${ }^{173}$ See Thel, 42 Hastings L J at 400 (cited in note 144); Thel, 42 Stan L Rev at 421-24 (cited in note 100). See also Ralph F. De Bedts, The New Deal's SEC: The Formative Years 81 (Columbia, 1964) (arguing that extensive delegation of authority to the SEC is a principal source of strength of the federal securities laws).

${ }^{174} 15$ USC $\$ \S 77 \mathrm{k}, 77 l(2)$.

175 See id $\$ 77 k(b)$. 
Put in its original context, however, issuer liability is not inconsistent with the agency cost explanation.

Two remedies were available under the common law to a purchaser of securities who relied on an inaccurate prospectus. The first was to sue the directors for deceit. In Derry $v$ Peek, ${ }^{176}$ the House of Lords concluded that fraudulent intent was necessary to support an action against directors for a misleading prospectus. Parliament responded to Derry $v$ Peek by enacting the Directors Liability Act 1890, which made directors liable for misstatements in prospectuses even absent fraudulent intent. ${ }^{177}$ The principal liability provision of the Securities Act, Section 11, tracks the language of the Directors Liability Act very closely, with the addition of issuer strict liability. ${ }^{178}$

Issuer liability essentially replicates the second remedy available to a purchaser of securities under English law, which was to rescind the purchase contract. ${ }^{179}$ That remedy makes a great deal of sense in the context in which it most typically arose-the discovery of a misleading prospectus (often by virtue of nondisclosure of the vendor's or promoter's financial interest) shortly after the initial subscription for shares. ${ }^{180}$ The shareholders' hope was to recover money paid for shares before the money could flow out to the promoter and/or vendor. Had the money already gone, the company itself could try to recover from the promoter and vendor. As a fiduciary for the company, the promoter was subject to an order for rescission. The vendor was often involved sufficiently in the creation of the company to be found a "promoter" as well, thus making the purchase price recoverable from him too.

The Securities Act, like the 1929 Act, is not by its terms limited to securities issues by promotional companies, so Section 11 can-and today usually does-operate to force one innocent group of shareholders to make good the losses of another innocent group. That possibility may not have impressed itself strongly on Congress, however, given the history on which it drew.

17614 App Cas 337, 343 (HL 1889) (Halisbury opinion).

17753 \& 54 Vict, ch 64 (1890).

17815 USC $\$ 77 \mathrm{k}$.

179 See, for example, Central Railway Co. v Kisch, 2 Eng \& Irish App 99, 121 (1867) (Chelmsford opinion).

${ }^{180}$ See id at 100-07; Erlanger $v$ New Sombrero Phosphate Co., 3 App Cas 1218, 121821 (HL 1878). 


\section{From Agency Costs to ACCURACy ENHancement-AN EFFICIENCY ANALYSIS}

The Securities Act and Exchange Act can, without straining, be read to authorize a disclosure system in which only agency information is mandated, and in which the remainder of corporate disclosure is left to private ordering, although subject to liability for misleading statements. That is not what happened. The SEC and the courts concluded that Congress had intended to mandate disclosure of every piece of information an investor might want to have in order to make a decision whether to invest. Indeed, the alleviation of agency problems would later be identified as an indirect benefit of the "full disclosure" philosophy. ${ }^{181}$

In recent years, the SEC has used the language of efficient markets to explain some of its disclosure initiatives. Over the last twenty-five years, the SEC has carried out a variety of farreaching extensions of the disclosure system, including segment reporting, management's discussion and analysis, a limited degree of current value accounting, and an attempt to bring management projections into the mandatory disclosure system. ${ }^{182}$ Each of these has been justified in part by reference to the accuracy enhancement goal. Does this relegate the agency cost model to the status of a historical curiosity?

I argue not, but on normative grounds. This Part examines efficiency arguments in favor of the agency cost model and the accuracy enhancement model, and concludes that efficiency considerations weigh in favor of limiting mandatory disclosure to agency information. For some readers, the above history by itself will be suggestive. Agency cost disclosure serves a typical private law function of providing, ex ante, a rule designed to facilitate a particular form of bilateral contractual relationship by economizing on transaction costs. Accuracy enhancement disclosure, in contrast, serves a typical regulatory function of coordinating, both through ex ante rules and ongoing government oversight, a myriad of interactions among a vast array of economic agents. It is widely accepted among law-and-economics scholars that governments can do a reasonably good job at the former. It is much

191 See Disclosure to Investors: A Reappraisal of Federal Administrative Policies under the '33 and '34 Acts 50-51 (Disclosure Policy Study, 1969) ("Wheat Report").

${ }_{182}$ See Kitch, The Theory and Practice of Securities Disclosure at 28-88 (cited in note 4). 
more sharply debated whether governments can effectively perform the latter function. ${ }^{183}$

\section{A. Efficiency and Agency Information}

It is common to analyze the efficiency of an implied contractual duty by asking whether most parties would likely choose the rule if given an opportunity to bargain. ${ }^{184}$ Adopting this mode of analysis, it is plausible that promoters, managers and investors bargaining ex ante would choose a rule under which agency information must be disclosed.

The relationship between a promoter and an investor bears a family resemblance to other relationships in which fiduciary duties arise, such as those between stockbrokers or real estate brokers and their customers. The promoter often has (and encourages investors to believe he has) specialized knowledge concerning the availability of unincorporated businesses that might be profitably converted into corporate form, as well as expertise in effecting the conversion. It is difficult for the investors to monitor the promoter's performance. The investors are likely much less well informed than the promoter about the availability of comparable businesses for sale, or about the prices and other terms of recent sales of privately held companies.

It would make sense for the investors to desire expert assistance in identifying and purchasing privately held businesses, and for promoters to provide such assistance. In this situation, however, the investors would likely insist on something akin to a duty of loyalty. Such a duty would help assure that the promoter does not take advantage of his special expertise to obtain a profit in excess of the compensation explicitly or implicitly agreed to by the investors. This can be accomplished in a relatively straightforward manner by an obligation to disclose the existence and extent of conflicting interests. Faced with a promoter who discloses a substantial adverse interest, most investors would refuse to invest unless they were assured that someone-either a knowledgeable and independent board of directors or a sophisticated "lead"

183 A brief but informative intellectual history of the antiregulation movement appears in George L. Priest, The Origins of Utility Regulation and the "Theories of Regulation" Debate, $36 \mathrm{~J}$ L \& Econ 289, 289-95 (1993).

${ }_{184}$ See Frank H. Easterbrook and Daniel R. Fischel, Contract and Fiduciary Duty, 36 J L \& Econ 425, 426-27 (1993); Charles J. Goetz and Robert E. Scott, The Mitigation Principle: Toward a General Theory of Contractual Obligation, $69 \mathrm{Va}$ L Rev 967, 971 (1983). 
investor with a large sum at stake-was going to negotiate the terms on which the corporation would be willing to purchase the promoter's property and services. The disclosure rule is therefore, in Frank Easterbrook and Daniel Fischel's phrase, "contractinducing." 185 It encourages the creation of the promoter/investor relationship, notwithstanding the promoter's potentially conflicting interests, by forcing the promoter to negotiate the terms of the self-interested transaction.

This duty is light compared to those imposed on other sorts of fiduciaries. Moreover, the duty is in the promoter's interest because it facilitates contracts under which promoters hire out their expertise to investors, thereby creating an additional means of profiting from that expertise. A promoter who purchases a property for resale and does not wish to disclose his purchase price can sell the business to a company with which he has no fiduciary relationship. Alternatively, he can seek equity financing from private sources, such as institutional investors, rather than the general public. Thus, a duty of disclosure does not eliminate the ability to profit from investing in information, as it might in some circumstances. ${ }^{186}$ Instead, disclosure makes possible an alternative contractual relationship under which the promoter sells his expertise to investors. To "sell" the expertise implies that the principal, not the fiduciary, is entitled to all of the marginal gains from the fiduciary's effort. But the fiduciary is free ex ante to seek a different type of relationship that divides the gains in a different manner. ${ }^{187} \mathrm{He}$ may not, however, create a mistaken expectation on the part of investors that they will be the beneficiaries of the promoter's expertise.

Requiring disclosure of executive compensation and self-dealing on an ongoing basis may also make sense. The benefits of such disclosure to the managers themselves are substantial. Just as the disclosure requirement imposed on promoters takes the place of the more intrusive duties of loyalty imposed on some other fiduciaries, so the manager's duty to disclose compensation

185 See Easterbrook and Fischel, $36 \mathrm{~J} \mathrm{~L} \mathrm{\&} \mathrm{Econ} \mathrm{at} 444$ (cited in note 184).

${ }_{186}$ See generally Anthony T. Kronman, Mistake, Disclosure, Information, and the Law of Contracts, $7 \mathrm{~J}$ Legal Stud 1 (1978) (suggesting that the absence of broad disclosure rules in contract law encourages the search for socially valuable information by giving the possessor of such information the option to deal with other parties without yielding his informational advantage).

187 For a discussion of different ways of rewarding an agent and the incentives created thereby, see Saul Levmore, Commissions and Conflicts in Agency Arrangements: Lawyers, Real Estate Brokers, Underwriters, and Other Agents' Rewards, 36 J L \& Econ 503 (1993). 
and self-dealing is a substitute for more stringent substantive limits on compensation and self-dealing. Corporate law permits managers to set their own compensation and engage in self-dealing transactions. ${ }^{188}$ Good arguments can be made that shareholders and managers would bargain to these permissive rules, but it is also plausible that shareholders would want to know the extent to which managers use this leniency.

But is it necessary to require specific disclosures? If both the market for capital and the market for managerial services are highly competitive, and if shareholders have rational expectations, then managers bear the losses caused by their self-interested behavior. ${ }^{189}$ Under those assumptions, promoters and managers have a strong incentive to take credible steps to reduce agency losses. To the extent that agency costs can be reduced by disclosure of agency information, promoters and managers will voluntarily provide whatever information investors desire, so long as the cost of production is less than the associated reduction in agency costs. ${ }^{190}$

Under the right assumptions, therefore, a legal rule mandating disclosure of agency information is unnecessary. At the same time, it is likely that the costs of such a rule are not much greater than the costs associated with voluntary disclosure, and they may even be less. Like many legal rules, a mandatory disclosure rule will be efficient if it saves parties from negotiating over the content of disclosure where the outcome is not likely to vary among firms, and thus the costs of complying with the one-sizefits-all rule are less than the costs of negotiating individual levels of disclosure. ${ }^{191}$

It is quite plausible that a mandatory disclosure rule would have exactly that result. The strongest case for the Securities Act's disclosure system is that it specified a limited and welldefined set of disclosures that virtually all firms would be expected to adopt. We know that, even prior to mandatory disclosure, experienced investors demanded and received information relat-

188 Under Delaware law, for example, a transaction between a director and the corporation is valid if either the disinterested board members or the shareholders approve it after disclosure of the "material facts" of the director's interest, or alternatively if the transaction is objectively fair to the corporation. 8 Del Code Ann \& 144(a) (1991).

${ }_{189}$ See Jensen and Meckling, $3 \mathrm{~J}$ Fin Econ at 318-19 (cited in note 5).

190 See Stephen A. Ross, Disclosure Regulation in Financial Markets: Implications of Modern Finance Theory and Signaling Theory, in Franklin R. Edwards, ed, Issues in Financial Regulation 177, 189 (McGraw-Hill, 1979).

${ }_{191}$ See id at 192 ("Even if disclosure regulation does nothing more than require the disclosure of information that firms currently disclose, it might be beneficial!"). 
ing to promoters' and managers' self-dealing and other forms of compensation. For example, the rules of the London Stock Exchange in the late nineteenth century permitted the listing of promotional companies only if the prospectus "states the amount paid, or to be paid, in money or otherwise, to concessionaires, owners of property, or others on the formation of the company [and the company authorizes] a member of the Stock Exchange ... to give full information as to the formation of the undertaking."192 Similarly, investors in any new venture would want to know what their ownership interest and formal rights would be relative to those of other classes of shareholders. Rules mandating disclosure of such information replicate, at lower cost, a hypothetical bargain among investors and promoters.

One objection to this analysis is that it demonstrates only that disclosure is an appropriate default rule. The Securities Act disclosure system, however, is not merely a default rule, the objection continues; its provisions cannot be waived. ${ }^{193}$ The objection is well-taken in theory, although it seems insignificant as a practical matter. Self-dealing and other forms of excessive compensation can have such a substantial impact on investors' returns that we would expect opting out to be very rare. ${ }^{194}$ Moreover, those investors most likely to waive the disclosure rule-wealthy, sophisticated investors who do not need to rely on the promoter's expertise - can opt out of the disclosure system by purchasing securities in private placements. ${ }^{195}$ And, of course, promoters may opt out by selling to a genuinely independent entity, thus avoiding the fiduciary relationship. Mandatory disclosure may therefore function more like a default rule than it appears at first glance.

\section{B. Efficiency and Accuracy Enhancement}

The majority of promoters, managers, and shareholders might agree to disclosure of agency information. Would they go 30).

152 London Stock Exchange Rule 136, reprinted in 1895 Report at 262 (cited in note

${ }^{193}$ See 15 USC $\$ 77 \mathrm{n}$.

194 A nonwaivable disclosure system can be analogized to other legal rules, such as the Statute of Frauds, that invalidate some untainted contracts on the theory that the costs created by invalidation are low compared to the benefits achieved through reduction in hard-to-prove frauds. See Richard A. Epstein, Unconscionability: A Critical Reappraisal, 18 J L \& Econ 293, 301-03 (1975).

19515 USC $\S 77 \mathrm{~d}(2)$ exempts from the registration (and therefore the mandatory disclosure) requirements, "transactions by an issuer not involving any public offering." 
beyond that and agree to disclosure of most or all information in the promoters' or managers' possession relating to the value of the firm? Let's begin by comparing accuracy-enhancing information to agency information. Agency information is limited in scope, can be described with reasonable precision, and is not costly to produce; in addition, its relevance does not vary dramatically among firms. None of these characteristics describes accuracy-enhancing information. The set of arguably relevant information is vast. Not only is the sheer volume immense, but it is difficult to specify ex ante what types of information are relevant without engaging in overkill. The factors that are most important to determining firm value vary substantially among firms. Thus, any disclosure system will either require vast quantities of irrelevant disclosure from many firms or ignore what will be for some firms the most important topics (or perhaps do both, as in the current system). It is therefore relatively easy to replicate firmby-firm bargaining over disclosure of agency information through a mandatory rule, but much more difficult to do so with respect to accuracy-enhancing information.

The cost of gathering data relevant to stock price is also higher than the cost of gathering agency information. The firm's managers are well-informed about their own activities and conflicts of interest. In contrast, they may have to expend considerable effort to produce information that investors would want in order to value the firm's securities. For example, assuming for a moment that separate financial information about each line of business and each geographic region is important to investors, the same information may not be important to firm managers. ${ }^{196}$ It is surely plausible that managers of some firms would not find it a useful exercise to attempt to allocate overhead expenses among product lines or geographic regions, but do so only because of the SEC's requirements. The same must also be true of current value accounting. Managers do not typically pay to have assets appraised on a periodic basis, so they must believe that the managerial benefits of having that information do not justify the costs.

No one would dispute the fact that a disclosure system predicated on accuracy enhancement is much more costly than one

196 The SEC requires for many businesses separate financial information about each "business segment," or line of business, engaged in by the issuer, as well as for each separate geographic region in which the issuer operates. See $17 \mathrm{CFR} \S 229.101(\mathrm{~b})$, (d) (1994). 
limited to a small amount of agency information. The argument for the former must be that its social benefits are correspondingly greater. The potential benefit is that a mandatory disclosure system might cause new information to be reflected in market prices more quickly or at less cost, or both, than a voluntary disclosure system.

This argument in support of the accuracy enhancement model draws on a distinction between the private and social benefits of information. ${ }^{197}$ The argument runs as follows: information relevant to the value of firms has social value that cannot be fully captured by any one actor. This "public good" characteristic implies that such information will be underproduced. Mandatory disclosure is a means of collectivizing the cost of a collectively valuable asset and solving the underproduction problem. At the same time, accuracy-enhancing information enables the person who first discovers it to make substantial profits. Accordingly, much of the investment in information that occurs is duplicative and, accordingly, wasteful. There can thus be both over- and underinvestment in information, resulting from the gap between private and social value. Mandatory disclosure helps close the gap.

1. Mandatory disclosure as a cure for overinvestment.

One of the arguments in favor of mandatory disclosure of accuracy-enhancing information is that it prevents or reduces investment in information that has private value but no social value. The argument stems from Jack Hirshleifer's demonstration that, under certain assumptions, the possessor of private information can use it to make profitable trades even though the information has no social value: that is, a single actor able to capture the net social wealth created by the information would not pay anything to have it. ${ }^{198}$ The legal literature has seized

197 The argument that the gap between the private and social value of information justifies the mandatory dislcosure system has been made most thoroughly by John Coffee, see Coffee, $70 \mathrm{Va} \mathrm{L}$ Rev at 725-34 (cited in note 2) (from which the summary in the text is taken), but the idea has been around for some time. See, for example, Report of the Advisory Committee on Corporate Disclosure to the Securities Exchange Commission, House Committee on Interstate and Foreign Commerce, 95th Cong, 1st Sess 626-28 (Committee Print 1977) (statement of William Beaver) ("Advisory Committee Report"); Nicholas J. Gonedes, Nicholas Dopuch, and Stephen H. Penman, Disclosure Rules, Information-Production, and Capital Market Equilibrium: The Case of Forecast Disclosure Rules, $14 \mathrm{~J}$ Acct Res 89, 96 (1976).

${ }_{193}$ See Jack Hirshleifer, The Private and Social Value of Information and the Reward to Inventive Activity, 61 Am Econ Rev 561 (Pt 1 1971). 
on Hirshleifer's analysis to suggest that there may be excessive investment by stock traders in information, because they can reap private benefits that may exceed the social benefits. ${ }^{199}$

The implications of Hirshleifer's results for securities regulation are both more limited and more complex than the legal literature indicates, for at least three reasons. First, Hirshleifer's model follows the assumptions of classical price theory and assumes that in a competitive market, any individual's trades do not affect the market-clearing price. ${ }^{200}$ We know that this assumption does not hold for securities markets because the prices of trades in those markets convey information and thereby affect the demand schedules of other traders. When prices reveal information, the gap between the private and social value of that information is reduced, and the problem of duplicative investment becomes self-correcting. ${ }^{201}$ As more traders invest in information, prices reflect that information, thus providing the information to previously uninformed traders at no cost, which in turn reduces the private incentive to gather additional information. Indeed, were prices fully revealing (that is, if prices adjusted instantaneously to new information), a gap would open in the other direction-information could have social value even though no trader could make a profit from investing in the information. ${ }^{202}$

Second, to the extent overinvestment exists, there are private means of reducing it. The existence of market letters and other types of research reports is evidence of voluntary cooperation-some market participants produce reports and others pay for them rather than compete for the same information. ${ }^{203}$ Other private arrangements, such as the New York Stock Exchange's procedures for suspension of trading pending the announcement and dissemination of material information, ${ }^{204}$ may serve to reduce the incentives for duplicative investments.

199 See Coffee, $70 \mathrm{Va} L \mathrm{Lev}$ at 733-34 (cited in note 2); Easterbrook and Fischel, $70 \mathrm{Va}$ L Rev at 682 (cited in note 2). See also Lynn A. Stout, The Unimportance of Being Efficient: An Economic Analysis of Stock Market Pricing and Securities Regulation, 87 Mich L Rev 613, 702-03 (1988).

${ }^{200}$ See Hirshleifer, $61 \mathrm{Am}$ Econ Rev at 564 (cited in note 198).

${ }^{201}$ See Sanford J. Grossman, The Existence of Futures Markets, Noisy Rational Expectations and Informational Externalities, 44 Rev Econ Stud 431, 436 (1977); Jerry Green, The Non-Existence of Informational Equilibria, 44 Rev Econ Stud 451, 453-54 (1977).

${ }^{202}$ See Grossman, 44 Rev Econ Stud at $\mathbf{4 3 6}$ (cited in note 201).

${ }^{203}$ See Gonedes, Dopuch, and Penman, $14 \mathrm{~J}$ Acct Res at 105 (cited in note 197).

${ }^{204}$ See New York Stock Exchange, Listed Company Manual III 202.06-202.07 at 2-4 to 2-6 (1992). 
The third limitation is that Hirshleifer's analysis tells us only that, where his assumptions hold, there will be too much investment in information. This is not the same as saying that public disclosure can eliminate this overinvestment. Where Hirshleifer's result holds, disclosure is beneficial only if it removes the incentive to make private investments-that is, if it provides information to all traders before any one of them can acquire it through other means. This is a very strong condition. It is clearly not met under the present disclosure system. The evidence is strong that the information in SEC reports cannot be used to generate trading profits, which is to say that the market is already efficient with respect to such information at the time it is disclosed. ${ }^{205}$ This means that traders are routinely obtaining information about company performance prior to the time it is disclosed in SEC reports.

One might respond that the reason traders are able to obtain the information prior to its formal disclosure is that management does not try to keep the information secret because it knows the information will eventually be disclosed. This observation is completely irrelevant, however, if the objective of disclosure is to prevent duplicative investments in information. The fact that prices already reflect the information contained in SEC reports proves that substantial, and potentially duplicative, investment in that information is taking place prior to the formal disclosure. The argument that there would be less informal disclosure in the absence of mandated disclosure may demonstrate that mandatory disclosure cures underproduction of information (a point discussed below), but not overproduction.

Ultimately, traders will not invest in information if they know that managers can take effective steps to keep the information a secret. On the other hand, if traders know that information can be obtained, they will devote money and effort to being the first to obtain it. The fact that everyone else will get the information at a designated time may create a greater sense of urgency, but it does not remove the incentive to get the information first.

Were we attempting to fix the disclosure regime to eliminate investments in information prior to the time of its public disclosure, we might make it illegal for corporate managers to make

${ }^{205}$ See Benston, $63 \mathrm{Am}$ Econ Rev at 139 (cited in note 1) (concluding, based on prior empirical work, that "[b]y the time of the final (SEC-required) report, there is almost no information that has not already been impounded in the price of the stock"). 
private disclosures prior to the filing of public disclosure documents. ${ }^{206}$ Such a policy would be both undesirable and unenforceable for two reasons. First, there is no obvious line between "private disclosure" and the use of information for business purposes. If a company's manager tells its principal supplier that the company desparately needs raw materials to meet unexpectedly strong demand for its product, this disclosure is in a sense private because the supplier or its employees may decide to buy the company's stock after they hear the information. At the same time, the statement may help the company get needed supplies more quickly. A rule forbidding such statements would be ridiculously counterproductive, but absent such a rule, informational asymmetries among traders (and accordingly overinvestment) will continue to exist.

The second problem is that managers are not the only ones who produce or obtain information about the company's performance. Managers may be the only source, or the best source, of some types of information, but a company's employees, suppliers, competitors, and creditors, among others, also generate valuable information about the company. It seems neither possible nor desirable to tell all of these actors that they may not trade on the information they generate, nor disclose it to others who might trade, until the information is contained in a public disclosure statement.

The alternative to forbidding private disclosure prior to the time of public disclosure is to speed up the disclosure system to the point where it is difficult to uncover the information prior to the time it becomes public. ${ }^{207}$ The more quickly the information reaches the public, the less time traders have to profit from the information, and (perhaps) the less investment traders will make in trying to beat the clock. That proposal is only superficially attractive. As the speed of disclosure increases, its accuracy will naturally decrease. The hours that accountants and lawyers now

${ }^{206}$ The SEC has made no serious effort to stop issuers from making disclosures outside the scope of the prospectus to institutional investors, and has only sporadically attacked managers for disclosing internal projections to analysts, despite its obvious discomfort over both practices. See Tom Pratt, The IPO Information Gap, Investment Dealers' Digest 15 (May 18, 1992); Note, Rule 10b-5 and Voluntary Corporate Disclosures to Securities Analysts, 92 Colum L Rev 1517, 1530-31 (1992) (describing SEC action in 1991 against a corporate insider who made disclosures to analysts and suggesting that it may show an SEC policy to discourage such disclosures).

${ }_{207}$ See Donald C. Langevoort, Information Technology and the Structure of Securities Regulation, 98 Harv L Rev 747, 786-89 (1985) (suggesting that an electronic system of "continuous disclosure" would reduce problems associated with private disclosure). 
routinely spend poring over disclosure documents to catch errors prior to filing would be jettisoned. Private investments in verification would become more profitable, because the first trader to spot a mistake in the real-time disclosures might be able to profit from the discovery. The focus of investment would therefore shift from discovering information to discovering mistakes in the continuous flow of disclosures, but overinvestment would still exist. Moreover, in stock trading, even very small increments of time matter. In a speeded-up disclosure system, the competition to get the information first would continue, but the sense of urgency would be heightened. Traders might hire more assistants and buy more computers to gather and analyze information more quickly, and might purchase more expensive communications systems to gather information as well as to transmit orders to the trading markets more quickly than their competitors. It is not obvious that the total amount invested in information would decrease.

2. Mandatory disclosure as a cure for underinvestment.

Many of the observations made above with respect to overinvestment apply to underinvestment as well. Capital markets help to narrow the gap between the private and social value of information. While informational efficiency assures that private value cannot be substantially greater than social value, market inefficiency prevents too wide a gap from opening in the opposite direction. Markets are just inefficient enough to make gathering information a profitable activity. ${ }^{208}$ The first trader to obtain accurate information bearing on the value of a company can capture some (but not all) of the trading profit to be had from that information. We know, then, that traders have substantial incentives to invest in information, and that many traders do so. Some of the private institutional arrangements that correct for the overinvestment problem can also correct for the underinvestment problem. The voluntary collectivization of information gathering through market letters and other reports serves

298 The theoretical case for profitable information arbitrage is made by Sanford Grossman and Joseph Stiglitz, On the Impossibility of Informationally Efficient Markets, 70 Am Econ Rev 393 (Pt 1 1980). For a consistent empirical result, see David F. Larcker and Thomas Lys, An Empirical Analysis of the Incentives to Engage in Costly Information Acquisition: The Case of Risk Arbitrage, $18 \mathrm{~J}$ Fin Econ 111 (1987). 
to create a property right in information that encourages its production.

Despite these corrective mechanisms, we might believe that less information relevant to the value of firms would be produced, absent mandatory disclosure. (The issue is not the sheer quantity of data, but the amount of value-relevant information; if the mandatory disclosure system produces information that is irrelevant to stock prices, it does not meet the efficiency criteria of the accuracy enhancement model.) Because the disclosure system's mandates are addressed principally to company managers, we must further believe that, absent legal compulsion, those managers would effectively conceal information.

One shortcoming of this theory is that it views information in firms as flowing primarily from the top down; if management wishes, it can turn off the tap and less information will flow. This is incorrect. Much, perhaps most, information within a firm flows from the bottom up. Of course, information is collected, categorized, and analyzed by management, and it is undoubtedly more useful to traders having undergone that process. But the raw data flows throughout the organization. Moreover, the data cannot be contained within the company itself (even assuming that the notion of the company as having discrete boundaries makes any sense). Every sizeable company has thousands of interactions with other economic agents every day. It negotiates, buys and sells, enters into contracts, borrows money, and makes and receives payments. These interactions convey information about the company's performance.

Consider a manufacturing enterprise that suddenly experiences a significant increase or decrease in orders. Its raw materials suppliers will soon be aware of a change in the quantities of raw materials the firm orders. Transportation companies will notice a change in the quantity of deliveries to and pickups from the firm's premises. The firm's labor unions will observe that the number of employees is changing more than usual. The firm's banks will notice changes in drawdowns on its working-capital loan facility, as well as changes in the flow of cash through its current account. Other suppliers of services to the firm, such as travel agents and telecommunications companies, may observe changes in the quantity of services consumed by the firm. These effects will be evident in a matter of days, while the underlying transactions would not show up in the company's periodic reports 
until the end of its current fiscal quarter, and possibly not until the end of the current fiscal year..$^{209}$

These pieces of information will not lie unnoticed, uncollected, and unused, given their potential value. Analysts and traders are likely to talk to many of the above entities; the entities themselves, as well as their employees, may trade in the firm's stock. Note also that the availability of this information is not a function of the mandatory disclosure system. ${ }^{210}$ It is created in a decentralized fashion and consequently cannot be easily concealed. Any attempt at concealment would require greater centralization, creating inefficiencies that would surely dwarf the gains to secrecy.

Anecdotes abound in the popular literature about clever investors who make good predictions about a company's performance from careful observation of generally available information. "Adam Smith" tells a story about Warren Buffett's purchase of a large stake in American Express just after that company's stock declined sharply as a result of a financial scandal. ${ }^{211}$

${ }^{209}$ An increase or decrease in orders does not fit within any of the items that must be reported currently on Form 8-K. See Form 8-K, General Instructions, 5 Fed Secur L Rptr (CCH) II 31,002 (Dec 21, 1994). At the end of the current quarter, the issuer would be required to file financial information pursuant to Form 10-Q. The effect of the increase or decrease may by that point be discernable from the financial statements. Form 10-Q also calls for a "management's discussion and analysis" (MD\&A"), and the increase or decrease in orders might constitute a "known trend" that must be disclosed in the MD\&A. See 17 CFR $\$ 229.303$ (1994). In any event, in the issuer's next annual report on Form 10$\mathrm{K}$, the backlog of orders would be disclosed pursuant to Item 101(c)(viii) of Regulation SK. 17 CFR § 229.101(c)(viii) (1994).

The observations made in the text do not depend critically on the company being publicly traded at the time the events occur. Similar information would be available from customers, suppliers, etc. of a company about to go public, and indeed we might expect customers and suppliers to purchase in the offering in an attempt to profit from their superior information.

210 Berle and Means's own description of the information available to the market in 1932 contrasts starkly with the notion that investors were largely in the dark prior to the federal securities laws:

Unofficially the market has collected around itself a tremendous mechanism for collection and dissemination of facts. These are made available through the standard publications (Poor's, Moody's Standard Statistics) and at more frequent intervals through the standard financial chronicles (as the Commercial and Financial Chronicle, Annalist, Dun's Review); and in still more transitory form, through the financial pages of the daily newspapers and certain papers which specialize in such matters (Wall Street Journal, New York Commercial); and from moment to moment, through the various ticker services. These, and many more besides, constantly pour into the market a running narrative of facts, figures, amounts, opinion, and information of all sorts ....

Berle and Means, The Modern Corporation at 294 (cited in note 154). 211 "Adam Smith," Supermoney 193 (Random House, 1972). 
Buffett went to a restaurant and counted the number of diners who paid by American Express traveler's checks and concluded that the company's core business was unaffected by the scandal; he bought heavily and made a large return on the investment. A popular book by an investment manager identifies appliance repairmen as an important source of investment information about companies selling consumer durables. ${ }^{212}$ Peter Lynch is said to have invested in Dunkin Donuts stock in part because he liked the coffee it served. ${ }^{213}$ Once again, this type of information is simply too widely available to be concealed, even if managers had some reason for wanting to conceal it.

We are nonetheless left with the fact that managers generally have some information that is unavailable to the rest of the market. The above analysis shows that this information is a smaller percentage of the total information bearing on stock price than it might at first seem, but nevertheless the information is valuable. Absent a mandatory disclosure system, managers would not have to share their deepest secrets with the rest of the market. But this is true even under our current mandatory disclosure system. As Edmund Kitch notes, the most plausible reason that issuers rarely complain about the mandatory disclosure system is that it does not require disclosure of anything sensitive. ${ }^{214}$ The system focuses almost entirely on backward-looking, factual data that is likely to be neither competitively sensitive nor easy to conceal.

Consider some hypothetical examples of information that might be in the possession of only a few employees and managers and that would significantly affect the stock price. A pharmaceutical company is on the verge of seeking a patent for a new drug. A mining company has identified what it believes is a significant ore body. Market research carried out by a large multinational company suggests that introduction of its product in China could increase worldwide sales by 25 percent. Each of these companies could omit any mention of the development in its SEC filings without violating the disclosure rules. ${ }^{215}$ Indeed, as a practical

212 See John Train, The Money Masters 68-69 (Harper \& Row, 1980).

${ }^{213}$ See Carolyn Friday, A Superstar Bids Farewell, Newsweek 38 (Apr 9, 1990).

${ }^{214}$ See Kitch, The Theory and Practice of Securities Disclosure at 119 (cited in note 4).

${ }^{215}$ Issuers filing a registration statement or periodic report are required to disclose the existence of a new product, business, or geographic market only if it has been announced or otherwise made public. 17 CFR $\$ 229.101$ (c)(ii) (1994). That provision goes on to note that "[t]his paragraph is not intended to require disclosure of otherwise nonpublic corporate information the disclosure of which would affect adversely the registrant's com- 
matter, the risk involved in not revealing positive information is extremely low. Outside the limited context of takeovers, a company that experiences a sudden increase in stock price has little to fear from the SEC or private litigants. ${ }^{216}$

This state of affairs could also be viewed as a mere design flaw to be corrected. It is hard to imagine, however, that it would be politically feasible to force companies to disclose competitively sensitive information. A system that attempted to force such disclosures, moreover, would be nearly impossible to enforce. The annoying thing about secrets is that you can't prove they exist. There is no effective way to make managers disclose what they are thinking. The net effect of such an attempt would be that fewer managers would commit their thoughts, beliefs, and plans to writing in order to make it possible to deny that they had such thoughts, beliefs, or plans.

This is not to say that management announcements never contain new information. There is empirical evidence that management announcements of earnings, dividends, and stock splits (which are typically made in advance of their reflection in SEC filings) sometimes contain new information. ${ }^{217} \mathrm{My}$ argument is simply that these particular management "secrets" have made it into the mandatory disclosure system without a political battle because managers have no desire to hide them. A company obviously cannot conceal the amount of dividends it pays or the fact that it is splitting its stock. Disclosure of earnings was routine for sizeable companies prior to $1933,{ }^{218}$ and even companies in lightly regulated markets such as Germany and Switzerland announce earnings. ${ }^{219}$ It strains credulity to think that absent

petitive position."

${ }^{216}$ Only a person who bought or sold the subject securities during the relevant time period has standing to bring a private securities fraud action; a person who failed to purchase because of misleadingly negative statements lacks standing. Blue Chip Stamps $v$ Manor Drug Stores, 421 US 723, 737-38, 749 (1975). Although a person who sold in response to a statement that turned out to be overly pessimistic could bring suit, the difficulty of proving damages appears to deter suit except in the takeover context, where the tender offer or merger price provides a convenient benchmark for measuring damages.

217 See, for example, Richard J. Rendleman, Jr., Charles P. Jones, and Henry A. Latané, Empirical Anomalies Based on Unexpected Earnings and the Importance of Risk Adjustments, $10 \mathrm{~J}$ Fin Econ 269 (1982); Joseph Aharony and Itzhak Swary, Quarterly Dividend and Earnings Announcements and Stockholders' Returns: An Empirical Analysis, 35 J Fin 1 (1980); Guy Charest, Split Information, Stock Returns and Market Efficiency-I, $6 \mathrm{~J}$ Fin Econ 265 (1978).

${ }_{218}$ Benston found that all New York Stock Exchange listed firms disclosed net income in each year from 1926 through 1934. George J. Benston, The Value of the SEC's Accounting Disclosure Requirements, 44 Acct Rev 515, 519-20 (1969).

${ }_{219}$ See, for example, German Analysts Offer High Hopes for 1994, Fin Times 21 (Aug 
the mandatory disclosure system, publicly held United States companies would cease making earnings, dividend, and split announcements.

\section{Can Mandatory Disclosure Solve Any Other Problems?}

It is worth noting the limitations of the arguments presented in this Part. I have not attempted to analyze the consequences of every possible mandatory disclosure rule. Rather, I have argued that mandatory disclosure is a plausible solution to the limited set of agency problems to which it originally was addressed, but that it is not a good solution to the more general problem of informational asymmetries among traders. This is not to say that there might not be some other problem to which mandatory disclosure, appropriately designed, might be a solution. ${ }^{220}$

At the same time, the more things a disclosure system attempts to do, the more substantial are the design problems facing its authors. The virtue of the mandatory disclosure system as initially developed in nineteenth-century England was that it was simple and its effects were felt principally by a class of firms-small, regional, newly-formed companies-for which the danger of sharp promotional practice was traditionally greatest. ${ }^{221}$ Neither of these observations is true with respect to the current mandatory disclosure system in the United States. It is accordingly no surprise that the system requires the production of staggering amounts of information yet fails to achieve the accuracy enhancement goal.

6-7, 1994) (discussing mid-year earnings reports of major German companies); Swiss Bank Corp Falls to SFr 1.19bn in First Half, Fin Times 18 (Aug 17, 1994) (discussing mid-year earnings reports of major Swiss banks).

${ }_{220}$ One concern of the framers of the Exchange Act was market manipulation. It is not universally accepted that manipulation of securities prices can be a profitable strategy. Compare Daniel R. Fischel and David J. Ross, Should the Law Prohibit "Manipulation" in Financial Markets?, 105 Harv L Rev 503, 512-23 (1991) (concluding that laws meant to deter manipulation of securities prices are unnecessary because such manipulation is hard to define and rarely profitable), with Steve Thel, $\$ 850,000$ in Six Minutes-The Mechanics of Securities Manipulation, 79 Cornell L Rev 219, 221 (1994) ("the evidence in the economic literature in fact indicates that manipulation is easier to accomplish than Fischel and Ross admit"). One who believes that manipulation is a problem might support a limited amount of disclosure of earnings and other significant performance data as a means of reducing the ability of potential manipulators to use deceit in furtherance of manipulation.

${ }_{221}^{22}$ The United States securities laws ultimately dealt with such companies in a very different way, largely by driving them out of the public markets and into the orbit of institutional investors. One might argue that this is a very sensible state of affairs; if so, it could surely be achieved more directly and at less cost. 


\section{SOME IMPLICATIONS OF THE AGENCY COST MODEL}

The accuracy enhancement model has affected disclosure policy. The SEC's initial response to the efficient markets hypothesis was to dismiss out of hand the notion that mandatory disclosure was unnecessary in an efficient market. ${ }^{222}$ It soon became obvious, however, that the language of efficient markets could be used to support as well as attack the mandatory disclosure system. Indeed, the essence of the accuracy enhancement model is its justification of mandatory disclosure as part of the mechanism by which markets become efficient. ${ }^{223}$ Accordingly, the SEC has undertaken several disclosure initiatives that are consistent with recommendations made by scholars who have employed the efficient markets hypothesis. ${ }^{224} \mathrm{My}$ description of these initiatives will be brief, as they have recently been described in detail by Kitch. ${ }^{225} \mathrm{My}$ aim is to use these initiatives to contrast the policy prescriptions of the agency cost model with those of the accuracy enhancement model.

\section{A. Disclosure of Projections}

One of the earliest and most persistent uses of the theory of efficient markets to criticize SEC disclosure policy dealt with management projections. ${ }^{226}$ There is nothing in the Securities Act or Exchange Act that requires disclosure of management's

222 The SEC commissioned an Advisory Committee on Corporate Disclosure. See Securities Act Rel No 5673, 1976 SEC LEXIS 2516 (Feb 2) (noting that since the time of the Wheat Report, "an increasing body of scholarly work," including the efficient markets hypothesis, has evolved, "and penetrating questions have been asked concerning the costs and benefits of the current system"). The Advisory Committee concluded that "notwithstanding the arguments of economists and others that the efficient market hypothesis... [has] rendered obsolete or unnecessary much or all of the mandatory disclosure system... these arguments are not sufficiently compelling to justify dismantling the existing system at this time." Advisory Committee Report at xlviii (cited in note 197).

${ }^{223}$ See, for example, Gilson and Kraakman, $70 \mathrm{Va} \mathrm{L} \mathrm{Rev} \mathrm{at} \mathrm{569-70} \mathrm{(cited} \mathrm{in} \mathrm{note} \mathrm{3);}$ Coffee, $70 \mathrm{Va} L$ Rev at 747 (cited in note 2); Kahan, 41 Duke L J at 979-81 (cited in note 3).

224 In addition to its use of the efficient markets hypothesis to justify the integrated disclosure system, see discussion in text accompanying note 237 , the SEC more recently cited the efficient markets hypothesis in support of the design of the US-Canada Multijurisdictional Disclosure System. See Securities Act Rel No 6841 (July 26, 1989), Fed Secur L Rptr (CCH) II 84,432 at 80,298 (1989 Transfer Binder). 4).

${ }_{225}$ See Kitch, The Theory and Practice of Securities Disclosure at 22-28 (cited in note

${ }^{226}$ See, for example, Homer Kripke, The SEC, the Accountants, Some Myths and Some Realities, 45 NYU L Rev 1151, 1197-1201 (1970); Benston, 63 Am Econ Rev at 137 (cited in note 1). 
plans or projections, nor is there anything that prohibits it. From the late 1930s until the late 1970s, however, the SEC had a policy against permitting the use of projections or other forwardlooking statements in a disclosure document, on the grounds that unsophisticated investors might be misled by a departure from purely factual information. ${ }^{227}$ The critics noted that in an effcient market, forward-looking information is much more valuable than historical information, which is already impounded in prices. After several rounds of proposals and comments, the SEC adopted Rule 175 in $1979 .{ }^{228}$ Rule 175 provides a "safe harbor" for certain forward-looking statements such as earnings projections and statements of management's plans or objectives. Such statements are deemed not fraudulent so long as they are made in good faith and with a reasonable basis.

The SEC explained the new rule by noting that "the availability of forward-looking and analytical information is important to an investor's assessment of a corporation's future earning power."229 Taken at face value, however, the accuracy enhancement model would take matters a step further. Disclosure of management's views about the future should not merely be permitted; it should be required, because those views are unquestionably an important piece of information that will affect the stock price if made public. The SEC stopped well short of that point. Its current stance is to "neither encourag[e] or discourag[e] the making and filing of projections." 230 However, it has recently announced its intention to reopen the question of disclosure of projections, requesting comment, among other things, on whether disclosure of projections should be mandated in some instances. ${ }^{231}$

From the standpoint of the agency cost model, the current stance is exactly correct. Disclosure of projections and other forward-looking information has nothing to contribute to the resolution of the promoter problem or the problem of management's self-interested use of the firm's assets. Such disclosures can

227 See Wheat Report at 96 (cited in note 181).

22817 CFR \& 230.175 (1994), adopted in Securities Act Rel No 6084 (June 25, 1979), Fed Secur L Rptr (CCH) I 82,117 (1979 Transfer Binder).

222 Guides for Disclosure of Projections of Future Economic Performance, Securities Act Rel No 5992 (Nov 7, 1978), Fed Secur L Rptr (CCH) I1 81,756 at 81,036 (1978 Transfer Binder).

230 Notice of Adoption of an Amendment to Rule 14a-9, Securities Act Rel No 5699 (Apr 23, 1976), Fed Secur L Rptr (CCH) II 80,461 at 86,202 (1975-76 Transfer Binder).

${ }^{231}$ Safe Harbor for Forward-Looking Statements, Securities Act Rel No 7101 (Oct 13, 1994), Fed Secur L Rptr (CCH) I 85,436 at 85,778 (1994-95 Transfer Binder). 
therefore be left unregulated. Investor demand for management projections and the cost of making them (including competitive losses) will determine the extent to. which such projections are made public.

\section{B. Current Value Accounting}

As described earlier, independently audited accounting statements can be viewed either as a means of helping shareholders to spot misbehavior by management or as a means of helping investors to determine the price of a security. Although it is not clear that the SEC would describe the dichotomy in this way, its views on accounting have been consistent with its views on projections. For most of its history, the agency rejected any departure from historical cost accounting statements, even if the departure consisted only of a supplemental disclosure of appraised asset values. ${ }^{232}$ More recently, the SEC has encouraged the accounting profession's standard-setting body, the Financial Accounting Standards Board ("FASB"), to take tentative steps toward current value accounting with respect to financial instruments.

This innovation is also a nod toward the accuracy enhancement model. The FASB itself was created because of the SEC's concern that the accounting profession had not responded with sufficient vigor to the conglomerate merger boom of the $1960 \mathrm{~s}^{233}$ Some commentators argued that these mergers were motivated in part by the desire to boost stock prices artificially using accounting gimmickry. ${ }^{234}$ Both the accounting profession and the SEC concluded that merger accounting standards were contributing to market inefficiency and that it was the job of the profession and the SEC to fix the problem. The FASB set about to revise merger accounting standards. On a more fundamental level, its first concept release stated that "[f]inancial reporting should provide information to help present and potential investors and other users in assessing the amount, timing and uncertainty of prospective cash receipts." ${ }^{\text {235 }}$

232 See R.G. Walker, The SEC's Ban on Upward Asset Revaluations and the Disclosure of Current Values, 28 Abacus 3, 122-24 (1992).

${ }_{233}$ See Loss and Seligman, 2 Securities Regulation at 703-12 (cited in note 78).

${ }^{234}$ See, for example, Burton G. Malkiel, A Random Walk Down Wall Street 56-64 (Norton, 1973).

${ }^{235}$ Financial Accounting Standards Board, Statement of Financial Accounting Concepts No. 1 viii (1978) (emphasis added). 
The notion that accounting standards can, and should, contribute significantly to price efficiency is consistent with the accuracy enhancement model. It also calls directly into question the appropriateness of historical cost accounting. ${ }^{236}$ The views of the accounting profession and the SEC therefore seem to be coming into line with the views of critics who have attacked the SEC's focus on historical cost accounting. It remains to be seen whether the relatively limited steps already taken toward current value accounting are the beginning of a fundamental shift.

From the perspective of the agency cost model, historical cost accounting is entirely adequate. The first and most important function of accounting statements is to enable shareholders to determine how the firm's assets are being used. Current value accounting provides information not only about the firm's actual transactions, but also about hypothetical transactions-the sale of corporate assets that are not actually for sale. At the same time, there is no reason to prohibit disclosure of current values. To the extent appraisals of assets provide useful information, there will be investor demand for such appraisals, which managers will or will not satisfy depending on the cost.

\section{Integrated Disclosure and Shelf Registration}

The SEC explicitly acknowledged the theory of efficient markets as a factor in its streamlining of the new-issue and periodic disclosure systems in the early $1980 \mathrm{~s}^{237}$ It noted that for large, established firms that are followed by analysts, previously-disclosed information should already be reflected in price. Accordingly, there should be no need to provide the same disclosures again in connection with a new issue of stock by such a company. The SEC's Integrated Disclosure System allows certain companies that are already subject to SEC periodic reporting requirements to file abbreviated new-issue disclosure documents that "incorporate by reference" the previously-filed periodic disclosure documents. ${ }^{238}$ In addition, companies that have been filing reports for twelve months and that meet certain other requirements are eligible for "shelf" registration, under which they may

${ }^{236}$ See Kripke, 45 NYU L Rev at 1188-96 (cited in note 226).

${ }_{237}$ See Securities Act Rel No 6383 (Mar 3, 1982), Fed Secur L Rptr (CCH) II 72,328 (Accounting Series Transfer Binder) (adopting integrated disclosure system).

${ }_{238}$ See, for example, Form S-3, General Instructions, 2 Fed Secur L Rptr (CCH) II 7152 (July 7, 1993). 
register an amount of securities to be sold on a periodic basis without the need for further registration or SEC review. ${ }^{239}$

From an agency cost perspective, these innovations move in the correct direction. They do not go far enough, however, because they were made for the wrong reasons. The key characteristic of "seasoned" companies is not that they are followed by analysts and priced efficiently, but that they have moved out of the promotional stage. Accordingly, the range of agency problems that disclosure can solve is reduced. The remaining problems are principally executive compensation and self-dealing (and perhaps underwriters' compensation, although the degree of independence between managers and underwriters should increase as a new company ages).

This would suggest that the SEC's current policies are too restrictive. In particular, the registration process for seasoned companies should be streamlined even more. A registration statement for an appropriately seasoned company could be made a mere "notice filing" that would become effective upon filing. ${ }^{240}$ Seasoned companies should be able to offer and sell securities at will using a nonmisleading prospectus that discloses the compensation and financial interests of the underwriters.

\section{Executive Compensation}

In 1992, the SEC adopted substantial changes to the required disclosures of executive compensation. ${ }^{241}$ One important change was to require more detail with respect to noncash compensation such as stock options and stock appreciation rights. ${ }^{242}$ In addition, information is required that implicitly invites from the shareholders a normative judgment about the amount of compensation the top executives receive. This latter information includes a comparison between the issuer's stock performance and both a market index and an index of peer companies, ${ }^{243}$ as well as a statement from the compensation committee of the

$23917 \mathrm{CFR} \S 230.415(a)(1)(x)$ (1994).

${ }^{240}$ Registration statements filed on Form S-3 that relate to dividend or interest reinvestment plans become effective upon filing. See Rule 462, 17 CFR § 230.462 (1994). The SEC could, if it desired, extend the same treatment to any registration statement filed on Form S-3.

${ }_{241}$ Executive Compensation Disclosure, Securities Act Rel No 6962 (Oct 16, 1992), Fed Secur L Rptr (CCH) I 85,056 (1992 Transfer Binder).

${ }^{212} 17$ CFR $\S 229.402(c)$, (d), (i) (1994).

${ }^{243}$ Id $\S 229.402(1)$. 
board of directors regarding the factors considered in setting the CEO's compensation. ${ }^{244}$

Criticism of the changes has taken two separate approaches. Some commentators have questioned whether the expanded disclosures of noncash compensation provide shareholders with any relevant information that was not already available to them. ${ }^{245}$ Other critics have charged that the new disclosures, particularly the compensation committee report, inject the SEC impermissibly into corporate governance. ${ }^{246}$

The latter argument is not new; similar challenges were made to the SEC's campaign against "questionable payments" (bribes) in the 1970s. ${ }^{247}$ From the standpoint of the agency cost model, criticisms of SEC disclosures on the grounds that they relate to matters of corporate governance are largely misplaced. Much of corporate governance has to do with reducing agency costs, so it is inevitable that mandatory disclosure, having the same focus, would sometimes encroach on the territory of corporate law.

At the same time, controversies surrounding the SEC's use of the disclosure system to police the governance of publicly traded companies raise a basic question about the design of securities regulation. Is securities regulation more properly part of corporate law (as it was for a long time in England) or a separate discipline? This is not merely a definitional issue in a federal system where corporate governance has been traditionally left to state law. The question became particularly acute when Congress decided to use mandatory disclosure not only to uncover agency information regarding promoters, but also to target corporate managers of publicly traded companies. While one might argue that the Securities Act dealt with an issue on the margin of corporate law (that is, the promoter problem), the Exchange Act created federal law at the very core of corporate governance.

I will not delve here into the debate between proponents of state and federal rules of corporate governance. ${ }^{248}$ The question

\footnotetext{
244 Id § 229.402(k).

${ }^{245}$ See, for example, Charles M. Elson, Executive Overcompensation-A Board-Based Solution, 34 BC L Rev 937, 956 (1993).

${ }^{245}$ See Comment, Regulation S-K, Item 402: The New Executive Compensation Disclosure Rules, 43 Case W Res L Rev 1175, 1185 (1993) (describing critical comments received during SEC rule-making process). 4).

${ }^{247}$ See, for example, Kripke, The SEC and Corporate Disclosure at 19-20 (cited in note

${ }^{248}$ For an excellent treatment, see Roberta Romano, The Genius of American Corporate Law (American Enterprise Institute, 1993).
} 
seems less acute, in any event, with respect to mandatory disclosure of a promoter's financial interest. The range of potential solutions to the promoter problem is not great. Most if not all Anglo-American jurisdictions that encountered the promoter problem ultimately arrived at similar solutions-the promoter had to disclose his financial interest, and in many instances also had to disclose the precise amount of profit he was making. A similar uniformity does not exist with respect to the alleviation of manager/shareholder conflicts, and thus the Exchange Act's disclosure requirements coexist less easily with state law than does the Securities Act.

\section{CONCLUSION}

The accuracy enhancement model of mandatory disclosure explains why a hypothetical disclosure system that required a firm to provide all value-relevant information simultaneously to all market participants could be efficient. This Article has argued that that analysis, important and interesting as it is, has little relevance to real-world mandatory disclosure systems. The existing mandatory disclosure system in the United States was not designed to provide all value-relevant information to all market participants, and after sixty years it remains rather far from that goal. Rather, the system was an incremental change from a longstanding set of judicial doctrines that were designed to combat a specific agency problem-the promoter problem. The most substantial innovation in the American mandatory disclosure system was the use of disclosure after the promotional stage to combat manager/shareholder agency problems, specifically management compensation and self-dealing.

The fact that mandatory disclosure began as a means of controlling agency costs does not mean that it should not be used to achieve the goal of accuracy enhancement if it can do so costeffectively. The hurdles blocking that result, however, seem dauntingly high. It is far from obvious that the involuntary collectivization of information can succeed where the involuntary collectivization of other productive assets has so notoriously failed. Success requires both the suppression of individuals' attempts to circumvent the system and, even more implausibly, competence bordering on omniscience on the part of the central authority that decides what information should be produced and how it should be distributed.

The issue of what mandatory disclosure can efficiently accomplish is perhaps more important today than it has been for 
decades. Stock markets are emerging in dozens of countries around the world, including those countries making the transition from central planning to a market economy. Policymakers are struggling to determine what regulatory systems are appropriate for fledgling markets. Given extremely scarce resources, emerging markets would do well to concentrate on the most costeffective regulatory steps first. In the field of mandatory disclosure, the most cost-effective step of all is to use a limited amount of disclosure aimed at promotional companies to combat the very large and persistent promoter problem. There is undoubtedly further debate to come on whether any additional steps can provide benefits in excess of their costs. 